"The impact of renewable versus non-renewable natural capital on economic growth"

Farid Gasmi, Laura Recuero Virto and Denis Couvet 


\title{
The impact of renewable versus non-renewable natural capital on economic growth ${ }^{+}$
}

\author{
Farid GASMI \\ Toulouse School of Economics \\ University of Toulouse Capitole \\ farid.gasmi@tse-fr.eu \\ Laura Recuero Virto - corresponding author ${ }^{++}$ \\ Museum National d'Histoire Naturelle and \\ Ministère des Affaires Etrangères et du Développement International \\ 27 rue de la Convention, 75015 Paris, France \\ laura.recuero-virto@diplomatie.gouv.fr \\ Denis Couvet \\ Museum National d'Histoire Naturelle \\ 43 rue Buffon, 75005 Paris, France \\ denis.couvet@mnhn.fr
}

\begin{abstract}
In a dataset on 83 countries covering the years 1960 through 2009, we find a negative indirect effect of the share of renewable natural capital in wealth on economic growth transmitted through demographic factors, more specifically, population fertility. In contrast, in countries with lower income inequality and higher institutional quality, the share of non-renewable natural capital in wealth has a direct positive impact on growth. We also find that countries with higher income per capita, human development, and institutional quality have a higher share of renewable natural capital per capita, but a lower share of renewable natural capital in wealth. Renewable natural capital is thus valuable for the population and of primary concern for empowered countries, even though it contributes less to wealth and economic growth. Our results raise serious questions about the way wealth and growth are defined in economics when one investigates the impact of natural capital and point to the importance of preserving natural capital, particularly, in less developed countries.
\end{abstract}

JEL-codes: O10, O13, Q20, Q30, Q32.

Key words: Natural capital, renewable, non-renewable, economic growth.

December 2019

\footnotetext{
${ }^{+}$The views expressed in this paper are our own and do not necessarily reflect those of the French Ministry of foreign affairs and international development. We are grateful to Carlos Romero, Antonio Casimiro Herruzo Martinez, Miguel Marchamalo Sacristan, Tiago Domingos, Emilio Jaime Cerda Tena, and Alejandro Caparros Gass for their suggestions. We thank as well the participants at the Séminaire du Centre International de Recherche sur l'Environnement et le Développement (CIRED), January 29, 2017, at the Séminaire Développement Durable Environnement et Economie Publique (DDEEP-EconomiX, Paris Nanterre), January 31, 2017 and at the Séminaire Café-scientifique du Centre d'Ecologie et des Sciences de la Conservation (CESCO, Museum National d'Histoire Naturelle), March 13, 2017. We would also like to thank Steven Durlauf and Grigoris Emvalomatis for insightful thoughts as well as for data and econometric programs shared at the $2^{\text {nd }}$ Advanced summer school in economics and econometrics at the University of Crete, Rethymno, August 19-26, 2007. We thank Enrique Moral-Benito for suggestions and data from Moral-Benito (2012) and Steven Poelhekke for data from van der Ploeg and Poelhekke (2010). Farid Gasmi acknowledges funding from the French National Research Agency (ANR) under the Investments for the Future (Investissements d'Avenir) program, grant ANR-17-EURE-0010.

${ }^{++}$Permanent address: Centre of law and economics of the sea, European Institute for Marine Studies, Building D, Rue Dumont d'Urville 29280 Plouzané, France. Email: laura.recuerovirto@univ-brest.fr.
} 


\section{Introduction}

The concept of "natural capital" aims to emphasize the role of nature in supporting the economy and human well-being (Pearce et al. 1989). In this article we distinguish between two types of natural capital resources depending on whether or not they are renewable and their social contribution. Renewable natural capital includes biodiversity, ecosystems, and their associated services, mainly providing non-market services, and also air and water. Nonrenewable natural capital includes mineral deposits and fossil fuels, which provide financial rents but do not generate direct services. ${ }^{1}$ Both types of natural capital provide people with exploitable resources (Petersen and Gocheva 2015). In this article, we use data on some renewable and non-renewable natural capital variables to develop a comparative analysis, based on cross-country estimations (World Bank 2006), of the impact of these two types of natural capital on economic growth. Renewable natural capital variables concern timber and nontimber forest resources, protected areas, cropland, and pastureland, and non-renewable natural capital variables include subsoil assets, namely, oil, natural gas, hard, and soft coal, and minerals.

Both types of natural capital are steadily decreasing, particularly when considering medium and long-term timeframes. Concerning renewable natural capital, the loss of ecosystem services is relatively significant and characterized by large geographical differences within and between countries (Costanza et al. 2014). The set of countries with the higher loss rates, amounting to more than $40 \%$, includes Tunisia, Haiti, and Libya (Sutton et al. 2016). Regarding non-renewable natural capital, its available stock has to be weighed against the potential demand of a growing and increasingly wealthier society (Andersson and Råde 2002). In the case of fossil energy, oil and gas are scarcer than coal. Concerning metals, platinum, gold, and rhodium are the least abundant (Goedkoop et al. 2008; Wegener Sleeswijk et al. 2008). Nevertheless, the amount of identified reserves typically increases with technological improvements, among other factors. ${ }^{2}$

Despite the context of natural capital depletion, the efforts to finance natural capital conservation are insufficient. For example, the resources currently being allocated to preserve and maintain biodiversity, about 50 billion USD per year, would at best cover one third of the lowest estimate of the needs. This financial support to protect biodiversity is mainly government-funded and poorly distributed (MAEDI 2014). As natural capital protection costs are high, the different stakeholders, from local communities to governments, are often reluctant to engage in such a protection in the absence of strong and convincing socio-economic arguments. Thus, unless academic researchers produce, in a comprehensible way for all stakeholders, knowledge on the social and economic relevance of such a protection, the situation may durably persist or even worsen. ${ }^{3}$ A key social and economic concern is the

\footnotetext{
1 Taxonomies of natural resources are typically controversial. The distinction between renewable and nonrenewable natural capital focuses on whether or not the use of resources may be irreversible. Alternatively, the degree of exhaustibility could be considered to reflect the rate of use whereby a resource may be non-renewable but abundant. A classification may also be based on the capacity to generate economic rents through the exploitation of the resource.

${ }^{2}$ There might also be a limit in the maximum usable amount of non-renewable resources due to the constrained planetary capacity to absorb the associated residues. Regarding fossil energies, for instance, $80 \%$ of fossil energy identified reserves should not be used in order to contain climate change (McGlade and Ekins 2015). Note, however, that scarcity cannot be assessed based on presently identified reserves, phosphate being a possible exception (Reynolds 1999).

${ }^{3}$ Needless to say that this research output ought to be translated into a set of planned actions in which policy makers and industry players are actively involved.
} 
improvement of human well-being that comes with economic growth and the very objective of this paper is to explore the nexus between variables that measure growth and natural capital. ${ }^{4}$

The issue of the effect of natural capital on the economy and the well-being of people is not well settled. ${ }^{5}$ According to the "natural resource curse" story that focuses on the "dependence" on natural capital, the latter impacts negatively economic growth as high levels of natural capital benefit a minority who controls access to natural resources by developing an extractive policy and often a poorly functioning political regime (Acemoglu and Robinson 2012). There is an alternative hypothesis that focuses on natural capital abundance and whereby the latter, in contrary, impacts positively economic growth (Brunnschweiler and Bulte 2008). This hypothesis is closely linked to the basic tenet that humans are highly reliant on a finite and non-growing ecosystem (Daly and Farley 2004). ${ }^{6}$

Understanding the role of natural capital in economic growth is contingent upon the definition given to natural capital. Also, in order to understand how natural capital contributes to economic growth, it is necessary to make a distinction between renewable and nonrenewable natural capital, as well as between direct and indirect effects on economic growth including the effects that work through international trade. Concerning the role of international trade, in particular, natural capital depreciation has been higher in poor countries than in rich countries (Barbier 2014), although poor countries have compensated this loss with higher capital growth (Barbier 2017).

In this paper we take the view that renewable and non-renewable natural capital impact economic growth in different ways, in particular, through variables that relate to various dimensions of human well-being as well as institutions, among other factors. Indeed, in addition to contributing to food provisioning, renewable natural capital provides local climate regulation, controls air and water quality, and mitigates natural hazards. Hence, it contributes indirectly but strongly to local wealth, quality of social relationships, health, and aesthetics. As a consequence, renewable natural capital may have a large indirect economic contribution to economic growth, particularly through health and, more generally, through human well-being (MEA 2005).

Non-renewable natural capital is necessary for industrial and agricultural activities, and can be a source of immediate financial wealth, which can have adverse social (Acemoglu and Robinson 2012) and environmental impacts through pollution depending, among other factors, on state regulations. The benefits of this natural capital can hence depend on the quality of the institutions, especially given that such capital can be more easily exchanged through international trade than renewable natural capital. A consequence is that the local negative environment effects of extraction due to pollution can be a source of competitive advantage in international markets for countries with low institutional quality. Companies, and indirectly governments, can promote exports of non-renewable natural capital with the help of certain regions' low social and environmental regulations associated with spillage effects (Barbier 2014; Lenzen et al. 2012).

Concerning direct and indirect social effects of natural capital on economic growth, social benefits associated with both kinds of natural capital also ought to be precisely defined. In regards to renewable natural capital, there is a need to identify the different human benefits that depend on human life-styles, representations, and values (Chan et al. 2012). It is also necessary to identify the natural entities necessary to provide these benefits. However, biologists barely

\footnotetext{
${ }^{4}$ The concept of ecosystem services precisely emphasizes the view that natural capital are assets that provide inputs and environmental services for economic production (Daily 1997), and their associated monetary value have been estimated (Costanza et al. 1997) though the precise meaning of a monetary value of services for which no markets exist has often been questioned.

${ }^{5}$ Shahnbaz et al. (2019) provide an interesting piece of empirical research as a survey on this controversy.

${ }^{6}$ Rockström et al. (2009) discuss a set of nine boundaries of the planetary ecosystem.
} 
know how biological (genetic and species) diversity affects the quantity and quality of ecosystem services (MEA 2005). In terms of non-renewable natural capital, the degree of substitutability, and hence the discount rate, is a critical factor to be accounted for (ten Brink et al. 2015). In particular, lower discount rates are more appropriate to take into account intergenerational equity as well as ethical responsibilities with respect to the world's poorest population that depend directly on natural capital (Gowdy et al. 2009).

It is also important to make a distinction between natural capital dependence and natural capital abundance, the former representing the share of natural capital in wealth and the latter the amount of natural capital per capita. The share of natural capital in wealth gives an indication of the stage of development, with a higher share indicating countries at an early stage of development in which their economy is mainly based on agriculture and natural resource extraction. In contrast, natural capital per capita indicates whether a country is rich in natural resources, in particular, whether it needs to import them. In the case of renewable natural capital, lower availability might impact health and quality of life. As previously explained, a strong dependence on agriculture and natural resource extraction is typically correlated with low economic growth, while a high ecological abundance in per capita terms contributes positively to economic growth (Gylfason 2011).

To the best of our knowledge, this article is an original contribution to the understanding of the role played by natural capital in economic growth while distinguishing the direct and indirect effects of its renewable and non-renewable components. Using a worldwide sample of countries, we estimate a class of models of the augmented Solow model types including new growth theories, in particular, the natural capital theory. In order to explore the existence of direct and indirect effects of natural capital on economic growth, we investigate the relevance of proximate and fundamental theories in explaining growth. More specifically, we examine whether natural capital impacts economic growth directly or indirectly through some other variables that, in turn, impact economic growth. We use a Bayesian Model Averaging (BMA) estimation approach relying on the results of a Classification Analysis and Regression Tree $(\mathrm{CART})$ model and, in addition, on making some ad-hoc choices. ${ }^{7}$ We produce some results on the impact of natural capital on economic growth for a set of country typologies, depending on investment in physical capital, based on the presence of multiple economic growth regimes, income per capita, income inequality, human development, and institutional quality.

The remainder of this article is organized as follows. In the next section, we review some related literature and discuss the empirical evidence produced by the stream of this literature that investigated the impact of natural capital on economic growth. In section 3 , we describe the econometric methodology used in this paper. In section 4 , we describe the data and some results from a preliminary analysis of the data. In section 5, we discuss the BMA estimation results that allow us to gauge the relative explanatory power of the different theories of growth considered in this article and highlight the main determinants of growth as well as the mechanisms through which their impact passes through. In section 6 we provide a critical summary of our main results from both a research and policy perspective. Three appendices provide tables containing details on the dataset analyzed, its sources, and the preliminary statistical and BMA estimation results discussed in the main text.

\section{Related Literature}

Progress in the integration of natural capital in national accounting and macroeconomic frameworks is necessary, especially for policy makers (Laurans et al. 2013; WWF 2015;

\footnotetext{
7 BMA is known to account for uncertainty in the selection among models that describe the data-generating process and is gaining increasing popularity in the social sciences. See, for instance, Moral-Benito (2012) for an application to cross-country panel data. A recent recent survey on the use of BMA in economics is Steel (2019).
} 
Recuero Virto et al. 2017). Early macroeconometric studies have uncovered a negative relationship between resource dependence and economic growth. Sachs and Warner (1995) find that resource-rich countries underperform resource-poor countries regarding export-led growth. Most of the analyses in the late 1990s and early 2000s also find evidence of such a negative relationship. These studies are usually based on cross-sectional regressions and resource dependence is usually proxied by the share of primary exports in total exports or GDP (van der Ploeg, 2010). The motivation behind this stream of research was mostly the difficulties of countries with non-renewable resources to transform these sources of wealth into economic growth (van der Ploeg 2010; Ross 2014).

Many of these studies have attempted to explain the causes of such a negative relationship between resource dependence and economic growth despite the fact that there is no universally accepted theory of the natural resource curse (Sachs and Warner 2001; Torres et al. 2013). A number of potential causes have been proposed, including the crowding-out of manufacturing activities, the political capture of rents, unsustainable government policies, poor investment in human resources, economic shocks, low institutional quality, armed conflicts, lack of effective property rights, high transaction costs, and volatility of world resource prices. ${ }^{8}$

Since about the mid-2000s, however, a number of studies have challenged the existence of a resource curse by providing evidence of a non-negative impact of natural resources on economic growth (Dinh and Dinh 2016). For instance, several articles have suggested that the negative relationship between natural resource dependence and economic growth can be reversed if institutional quality is sufficiently high (Boschini et al. 2013). In fact, some authors argue that the main difference between the cases of success and failure among countries that are dependent on natural resources is related both to the quality of institutions and political economy factors (Melhum et al. 2006; Torvik 2009).

Lederman and Maloney (2002) argue that the result that shows a negative impact of natural resources on economic growth may be due to the use of inadequate indicators, i.e., proxies, for natural resources and international heterogeneity. Concerning indicators, the adverse impact of resource dependence on institutional quality and economic growth would be indeed particularly strong for easily appropriable "point-source" rents that have a relatively concentrated production such as minerals, oil and plantation crops with coffee, sugar, banana, and tobacco compared to "diffuse rents" such as rice, wheat, and livestock for which production is more dispersed. ${ }^{9}$ Ades and Di Tella (1999) show by using cross-country regressions that the management of natural resources provides incentives for corruption among bureaucrats and politicians.

In addition, although natural resource dependence, measured by the share of exports of primary products in GDP or other ratio indicators, may slow economic growth, natural resource abundance, often measured by per capita value of production and reserves or stocks, may have no significant impact on, or affect positively, economic growth. ${ }^{10}$ Gylfason (2011) finds that a larger amount of natural capital assets per capita enhances economic growth, while a large ratio of natural capital assets in national wealth has the opposite impact.

Ding and Field (2005) find similar results to Gylfason (2011) but they are contingent on the type of model used. According to Cerny and Filer (2007), although a large ratio of natural

\footnotetext{
${ }^{8}$ See Frankel (2010) and Torres et al. (2013) for an exhaustive review of this literature.

${ }^{9}$ For more details on these points, see van der Ploeg (2010). Also, regarding the choice of natural resource indicators, when Lederman and Maloney (2008) use net exports of primary products per worker, Sachs and Warner (1995)'s negative impact of natural resources on economic growth based on share of gross exports of primary products in GDP disappears due to the possibility of re-exportation.

10 Alternative definitions of resource abundance have been proposed in the empirical literature. Norman (2009), for instance, defines resource abundance as the share of resource stocks in GDP or as resource stocks per capita and resource intensity as the ration of resource exports in GDP.
} 
capital assets in national wealth is associated with slow economic growth, there is no evidence that natural capital assets per capita are negatively correlated with growth. The negative relationship between resource dependence and economic growth would be due to the link between a small size non-resource sector and slow economic growth, which, in turn, would be caused by other unobserved characteristics of the economy.

According to Stijns (2005), the data on fossil fuel and minerals reserves show that natural resource abundance has not been a significant determinant of economic growth in the period 1970-1989. This would probably be due to the existence of both positive and negative effecttransmitting channels. Regarding a positive transmission channel, when a natural resource has high transportation costs, its physical availability within the economy is important for the development of related industries (De Long and Williamson 1994; Bardini 1997). Indeed, coal and iron ore deposits were a prerequisite for the development of the steel industry in the $19^{\text {th }}$ century, for instance.

Van der Ploeg (2010) does not find evidence of an impact of share of resource exports in GDP or subsoil assets on economic growth and concludes that this is probably because of the divergent impact of these variables on growth depending on the degree of volatility of commodity prices and exchange rates. Concerning production dependence, Hall and Jones (1999) and Sala-i-Martin et al. (2004) find a positive relationship between the share of mining in GDP and economic growth, the latter paper requiring conditioning mining on other variables to show its full impact.

As to the issue of accounting for the presence of international heterogeneity when analyzing the impact of natural resources on economic growth, the academic literature based on fixed-effects estimation provides evidence that dependence variables based on natural resource exports are not significant determinants of economic growth (Mansano and Rigobon 2001; Lederman and Maloney 2002). However, these fixed-effects methods leave unexplained the long-run cross-country growth variation that the studies sought to explore (Durlauf and Quah 1999). To account for international heterogeneity in measuring the relative impact of the determinants of growth, controlling for mean shifters by including regional dummies can be an alternative to fixed-effects estimation (Lederman and Maloney 2008).

From an econometric perspective, regression analyses have shown that a large number of variables are correlated with economic growth without necessarily implying a direction of causation. The lack of consensus on a theoretical model and subsequently on a reduced form to apply in empirical analyses has led some researchers to explicitly account for model uncertainty and let the data show which variables are correlated with economic growth (Capolupo 2009). In order to estimate accurately the role of the so-called new growth theories such as the natural capital theory in highlighting the determinants of economic growth and estimating their impact, Durlauf et al. (2005), Durlauf et al. (2008a) and Sala-i-Martin et al. (2004) have proposed the BMA method which we adopt in this paper. ${ }^{11}$

An additional difficulty in economic growth regressions estimation is that there might be multiple economic growth regimes, each regime with economies that tend to converge to one another (Durlauf and Johnson 1995). Under such circumstances, the usual practice is to divide the sample according to a cut-off point of a variable within the database either relying on the results of a given methodology or making an ad-hoc choice. ${ }^{12}$ Konte (2013), for instance,

\footnotetext{
${ }^{11}$ Fernandez et al. (2001) show the superiority of the BMA method over other techniques in selecting regressors for cross-country growth regressions.

12 There are a number of studies that use a wide variety of statistical methods to identify multiple economic growth regimes (Durlauf et al., 2005). See Owen et al. (2007) and Konte (2013) for an overview of how the presence of multiple economic growth regimes has been addressed by dividing the sample according to different theories, mainly, neoclassical, geography, demography, and institutions.
} 
allows for the presence of multiple economic growth regimes and finds that democracy favors the contribution of natural resources to economic growth, while education has no effect.

\section{Econometric Methodology}

In this section, we first present the baseline model based on the augmented Solow model and a set of new growth theories. Then, we explain how we integrate theory and specification uncertainty through the BMA methodology. Finally, we describe how we develop our preliminary analysis on the existence of multiple economic growth regimes.

\section{Baseline Growth Model}

Since the variation of economic growth rates, typically at an annual frequency, may provide misleading information on the long-term growth process, it is necessary to average the data. ${ }^{13}$ In the same spirit as Durlauf and Quah (1999), we specify an augmented Solow neo-classical growth model that includes a set of new growth theories (Solow 1956; Durlauf et al. 2005; Durlauf et al. 2008a) as follows:

$$
\begin{array}{r}
\bar{g}_{i, t}=\gamma_{0} \log \left(G_{i, t-\bar{T}}\right)+\gamma_{1} \log \left(s_{i, t}^{k}\right)+\gamma_{2} \log \left(s_{i, t}^{h}\right)+\gamma_{3} \log \left(n_{i, t}+g+\delta\right)+ \\
z_{i, t}+\alpha_{i}+\theta_{t}+\varepsilon_{i, t}
\end{array}
$$

where the subscripts $i=1,2, \cdots, N$ and $t=1,2, \cdots, T$ indicate the country and the year respectively, $\bar{T}$ is the length of the averaging period, $\bar{g}_{i, t}$ is the average growth rate of real GDP per capita over the periods $t, t+1, t+2, \cdots, t+\bar{T}, G_{i, t-\bar{T}}$ is the real GDP per capita at the beginning of the period, and the variables $s_{i, t}^{k}, s_{i, r}^{h}$ and $\log \left(n_{i, t}+g+\delta\right)$ are neoclassical growth theory measures of the net accumulation of factors. More specifically, $s_{i, t}^{k}$ represents the saving rate of physical capital accumulation or the investment in physical capital, $s_{i, t}^{h}$ is the saving rate of human capital accumulation or the investment in schooling, $n_{i, t}$ is the population growth rate, $g$ is the augmenting technical progress parameter, and $\delta$ is the physical capital depreciation rate. $^{14}$

Next to these standard neoclassical independent variables, the variable $z_{i, t}$ represents a set of proxy variables that allows us to incorporate in our framework eight new growth theories that are described in Table 1 below and in Tables A.1 and A.2 in the appendix, $\alpha_{i}$ and $\theta_{t}$ are variables that capture country- and time-specific effects respectively, and $\varepsilon_{i, t}$ is an error term. As to the coefficients of the regression (1), the parameter $\gamma_{0}$ is an unknow constant and

$\gamma_{1}=e^{\lambda \bar{T}}, \gamma_{2}=\left(1-e^{\lambda \bar{T}}\right)\left(\frac{\alpha_{k}}{1-\alpha_{k}-\alpha_{h}}\right), \gamma_{3}=\left(1-e^{\lambda \bar{T}}\right)\left(\frac{\alpha_{h}}{1-\alpha_{k}-\alpha_{h}}\right), \gamma_{4}=-\left(1-e^{\lambda \bar{T}}\right)\left(\frac{\alpha_{k}+\alpha_{h}}{1-\alpha_{k}-\alpha_{h}}\right)$

\footnotetext{
${ }^{13}$ Even though averaging enables one to deal more adequately with business cycle effects, the sample size and the presence of heteroscedasticity and serial correlation constitute constraints on the time horizon over which this averaging exercise can be performed. Indeed, the longer this time span, the smaller the number of degrees of freedom and hence the less accurate the estimates are and the less explanatory power the regressors have (Durlauf et al. 2008b). In this paper, we use an averaging time span of 5 years.

${ }^{14}$ A typical assumption is that the rate of technical progress and the physical capital depreciation rate add up to $5 \%$, i.e., $g+\delta=0.05$ (Mankiw et al. 1992).
} 
where $\lambda<0$ is the rate of growth convergence and $\alpha_{k}, \alpha_{h}>0$, such that $\alpha_{k}+\alpha_{h}<1$, are the elasticities of output with respect to, respectively, physical capital and human capital in a CobbDouglas production function assumed to exhibit decreasing returns to scale.

Each of the added new growth theories mentioned above can be proxied by several variables within $z_{i, r}$ (see Table 1). A proxy variable is used to represent an unobserved metric, that is, in our case, a character that identifies a given growth theory. For example, life expectancy and fertility rate are very good candidate variables for proxying the demography growth theory. When several proxies are used for a given theory, one can disentangle the effects of each proxy. For example, it is possible to explore whether the variable Eastern religion has a significant impact on economic growth relative to the other religions that are examined.

Table 1. Proximate and fundamental growth theories and some proxies

\begin{tabular}{|c|c|}
\hline Proximate theories & Proxies \\
\hline$\overline{\text { Neoclassical }}$ & $\begin{array}{l}\text { Initial income, Population growth rates, Investment in physical } \\
\text { Capital, Investment in schooling (Solow 1956) }\end{array}$ \\
\hline Demography & Life expectancy, Fertility rate (Shastry and Weil 2003; Weil 2005) \\
\hline Macroeconomic policy & Openness, Government consumption, Inflation (Barro 1997) \\
\hline Regional heterogeneity & $\begin{array}{l}\text { Latin America and Caribbean, Sub-Saharan Africa, East Asia, } \\
\text { The Pacific and South-East Asia (Brock and Durlauf 2001) }\end{array}$ \\
\hline Fundamental theories & Proxies \\
\hline Religion & $\begin{array}{l}\text { Buddhism, Catholicism, Eastern religion, Hinduism, Judaism, Islam, } \\
\text { Orthodox religion, Protestantism, Other (Barro and McCleary } \\
\text { 2003; Durlauf et al. 2012) }\end{array}$ \\
\hline Natural capital & $\begin{array}{l}\text { Natural capital in wealth, Natural capital per capita } \\
\text { (Sachs and Warner 1995; Gylfason 2011) }\end{array}$ \\
\hline Geography & Coastline, Landlocked (Sachs 2003) \\
\hline Fractionalization & $\begin{array}{l}\text { Language, Ethnic group (Alesina et al. 2003; Easterly and } \\
\text { Levine 1997) }\end{array}$ \\
\hline Institutions & $\begin{array}{l}\text { Liberal democracy, Public sector corruption, Legal } \\
\text { formalism, Governance and executive constraints } \\
\text { (Djankov et al. } 2002 \text { and 2003) }\end{array}$ \\
\hline
\end{tabular}

In Table 1 economic growth theories are classified into two classes, namely, proximate and fundamental or deep theories (Rodrik, 2003). This distinction between proximate and fundamental theories enables us to explore the existence of direct and indirect effects of natural capital on economic growth. The question we ask then is whether natural capital impacts economic growth directly or indirectly through some other variables that, in turn, impact economic growth. Durlauf et al. (2008a) consider the neoclassical, the demography, the macroeconomic policy, and the regional heterogeneity theories of growth as proximate, and the religion, the natural capital, the geography, the fractionalization, and the institutions theories of growth as fundamental, the latter broadly encompassing cultural and natural determinants of growth.

Proximate theories are associated with the human and physical capital factor inputs and their productivity in the production of a flow of goods and services (Rodrik, 2003). They can also include other determinants that can be rapidly influenced by policy measures (Durlauf et al., 2008b). The deep sources of economic growth lie in those variables that have a significant influence on a country's ability to accumulate production factors and to invest in the production of knowledge (Acemoglu et al., 2005). In contrast to proximate determinants, fundamental determinants tend to depend on slow-moving parameters (Durlauf et al., 2008b). 
Our economic growth regressions include proxies for both proximate and fundamental theories of growth. We will say that a given theory provides a satisfactory explanation for growth if the estimated coefficient of at least one variable that proxies this theory is statistically significant. Proximate theory proxy variables can only have direct impacts on economic growth whereas fundamental theory proxy variables can have direct and/or indirect impacts. Hence, to uncover a direct impact on growth, regressions should include both proximate and fundamental theories' proxy variables referred to as, respectively, "proximate variables" and "fundamental variables." If proximate variables or fundamental variables were significant, this would imply that the corresponding theories have a direct explanatory power of economic growth. To uncover indirect impacts of fundamental theories' proxy variables on economic growth, growth regressions should only include fundamental theories' proxy variables. When fundamental variables are significant, while they were not when both proximate and fundamental variables are included, we conclude that the corresponding fundamental theories have an indirect explanatory power that passes through the proximate theories channel. Correlations between proximate and fundamental variables are also analyzed to provide some alternative evidence on the relationships between these two sets of theories.

\section{Model and Specification Uncertainty}

As indicated in the introduction the BMA estimation approach that we use allows us to estimate regressions aimed at testing alternative theories of economic growth while explicitly accounting for the associated models' uncertainty and the uncertainty related to the specification of proxy variables for each theory to be used as regressors (Brock and Durlauf 2001; Brock et al. 2003). More specifically, let $m$ designate an economic growth model in the model space $M$ given an available data $D$. Then, this model's posterior probability is given by

$$
\mu(m \mid D)=\mu(D \mid m) \mu(m)
$$

where $\mu(D \mid m)$ is the likelihood of the data given the model and $\mu(m)$ is the prior probability of the model $m$. In our empirical analysis, we set the prior probability that a particular theory is in the true model to 0.5 to reflect no discrimination and non-information across theories (Durlauf et al. 2008a). Given $\mu(m \mid D)$ expressed in equation (3), we then estimate the probability, $P_{\xi}$, that a given theory, $\xi$, is in the true model, as the aggregate probability

$$
P_{\xi}=\sum_{m \in \mathrm{M}} \mu(m \mid D, m \in A)
$$

where $A$ is the event

\{At least one proxy variable associated with the theory is in the true model\}

\section{Multiple Growth Regimes}

Prior to estimating the regression given in equation (1), we explore whether or not there are multiple economic growth regimes. The so-called "conditional beta-convergence" is interpreted as evidence that poorer countries experience growth rates that convergence to those of richer countries after controlling for heterogeneity. Alternatively, there can be multiple economic growth regimes when no single regime model can explain global convergence (Durlauf and Johnson 1995). Hence, initial conditions contribute to explaining the cross-country economic growth variance after controlling for structural heterogeneity. ${ }^{15}$

\footnotetext{
${ }^{15}$ Note that the presence of multiple regimes may be due to multiple steady-states or to non-linearity of the growth process.
} 
To answer the question of whether or not there are multiple economic growth regimes we proceed in two steps. First, based on Durlauf and Johnson (1995), we apply the Classification Analysis and Regression Tree (CART) model to Solow variables so as to identify variables that are most likely to provide a "reasonable" separation of observations. We then estimate the augmented Solow model for the full sample and for the identified sub-samples, and we test the hypothesis that every sample follows the same convergence dynamics with a Chow test. This test allows us decide on whether or not economic growth regressions should be based on one sample or on several sub-samples. ${ }^{16}$

To perform these preliminary estimations, since the country-specific effect $\alpha_{\mathrm{i}}$ is not independent of $\log \left(G_{i, t-\bar{T}}\right)$, we can use a fixed-effects method. Another alternative is to difference the model to eliminate fixed-effects and then use the Differenced Generalized Method of Moments (DIF-GMM) method developed by Arellano and Bond (1991) to address the contemporaneous correlation between the differenced lagged dependent variable $\log \left(G_{i, t-\bar{T}}\right)$ component of $\Delta \log \left(G_{i, t-\bar{T}}\right)$ and the $\Delta \varepsilon_{i, t-\bar{T}}$ component of the new error term:

$$
\begin{gathered}
\Delta \log \left(G_{i, t}\right)=\gamma_{0} \Delta \log \left(G_{i, t-\bar{T}}\right)+\gamma_{1} \Delta \log \left(s_{i, t}^{k}\right)+\gamma_{2} \Delta \log \left(s_{i, t}^{h}\right)+\gamma_{3} \Delta \log \left(n_{i, t}+g+\delta\right)+ \\
\Delta z_{i, t}+\Delta \theta_{t}+\Delta \varepsilon_{i, t}
\end{gathered}
$$

To obtained equation (6), the dependent variable in equation (1) is transformed from an average growth rate, $\bar{g}_{i, t}$, to a logarithm of real per capita GDP. We follow the standard approach where lagged values of the potentially endogenous regressors in levels are used as instruments. However, if the explanatory variables have highly persistent effects, lagged variables in levels may be weak instruments to capture such effects and consequently the estimator can be biased. To check for the consistency of the DIF-GMM results, we compare the Ordinary Least Squares (OLS) estimates of the rate of convergence $\lambda$ and the within-group methods with those obtained with the DIF-GMM method. If the explanatory variables other than the lagged output are exogenous then a consistent DIF-GMM parameter estimate should lie between OLS and within-group estimates, which are biased in opposite directions (Caselli et al. 1996).

Moreover, lagged variables in levels can also be inappropriate instruments if there is serial correlation in the error terms of the growth equation before differencing. Given these drawbacks of the DIF-GMM method, we also estimate equation (3) with the system GMM (SYS-GMM) method developed by Arellano and Bover (1995). This estimator uses, in addition to the moment conditions used in the DIF-GMM method, instruments in first differences for the equation in levels and hence lead to more robust estimates.

\section{Data and Preliminary Analysis}

The unbalanced panel dataset that we have built contains information on 83 countries during 10 five-year periods from 1960 to 2009. The choice of the eight growth theories and the associated variables is largely inspired by the work of Durlauf et al. (2008a). There are some differences in the choice of variables, though. We include our variables of interest, that is, the share of natural capital in wealth and the natural capital per capita suggested by Gylfasson (2011). ${ }^{17} \mathrm{We}$

\footnotetext{
${ }^{16}$ The Chow test is based on an F-statistic given by $\left[r s s_{r}-\left(r s s_{1}+r s s_{2}\right)\right] / K\left(r s s_{1}+r s s_{2}\right)(n-2 K)$ where $r s s_{\mathrm{r}}$ is the residual sum of squares obtained from the full-sample model, $r s s_{1}$ and $r s s_{2}$ are the residual sum of squares of the two sub-sample models, $K$ is the total number of independent variables (including the constant), and $n$ is the total number of observations.

${ }^{17}$ The data has been subject to some criticisms (van der Ploeg and Poelhekke, 2010). For instance, a discount rate of $4 \%$ per year is applied independently of the rate of economic growth, and a remaining lifetime of 20 years and
} 
distinguish between renewable natural capital (timber, non-timber forest resources, protected areas, cropland, and pastureland) and non-renewable natural capital (oil, natural gas, hard coal, soft coal, coal, and minerals). ${ }^{18}$ The data also includes the effects that are related to directly using the resource (for instance, extracting timber) as well as those associated with some ecosystem services (ecosystem services from forests). The 2000 data point is used for natural capital variables to proxy slowly-varying natural capital measures over our timeframe.19

Compared to Durlauf et al. (2008a), we use the average growth rate of real per capita GDP instead of the average growth rate of real per worker GDP since Caselli (2005)'s dataset does not cover our period of study. For the geography theory, we use some variables suggested by Durlauf et al. (2005) since those used by Durlauf et al. (2008a) were often not available for our sample of countries. For the institutions theory, we use individual and minority rights and public sector corruption instead of expropriation risks since the latter was not available for our period of study. The detailed definition of the variables and the data sources are given in Tables A.1-A.2 in the appendix. We now turn to the discussion of the results of the preliminary analysis of the data.

The most relevant results of the preliminary analysis are given in Tables A.3-A.9 in the appendix. First, we present the summary statistics for all the variables used in our estimations. Second, we give the correlation coefficients between the proximate theories' proxy variables and the proxy variables associated with the fundamental theories when the level of correlation is greater than or equal to 0.40 . These correlations convey information on whether or not fundamental theories and, in particular, renewable and non-renewable natural capital may be good candidates as independent variables in the growth regressions and thus have some explanatory power that goes beyond the influence exerted through proximate theories. Second, we present the results of some preliminary tests for the purpose of preparing the data for the analyses. Third, we present the results of whether or not there is evidence in our dataset of multiple economic growth regimes by using the CART model. Fourth, we give the results of a check of the robustness of these results obtained with the OLS, the fixed-effects, the DIFGMM, and the SYS-GMM methods. Finally, we give the summary statistics and the correlation matrix according to the results of the CART model.

Before proceeding with the estimation of the CART model and the economic growth regressions, we develop a series of preliminary tests. We find that our dependent variable is stationary in levels, that panel data is preferred to pool data, and that heteroscedasticity and serial correlation are present in the data. We thus treat accordingly. ${ }^{20}$ We then develop the

the same elasticity of the cost of extraction are used independently of the type of resource, the country, and the date. In addition, Van der Ploeg (2010) argues that there is a caveat in using The World Bank data on resource stocks as a measure of abundance since it is based on rents.

${ }^{18}$ See World Bank (2006).

${ }^{19}$ While we realize that using 2000 data for natural capital may affect in a non-trivial way our results, we were constrained by data availability. In fact, as discussed in the concluding section of this paper, our analysis also points to the need to further develop better datasets on this crucial variable.

${ }^{20}$ First, using the Fisher unit root test we find that the dependent variable is stationary in levels. Second, we verify whether or not we should pool the data by testing the appropriateness of random and fixed-effects panel data compared to the pool analysis through the goodness-of-fit results. Panel data is preferred to pool data, which implies that the parameters of the equation vary from one period to the other over the ten periods of available data. Third, using the Erlat LM-test, we find that there is heteroscedasticity in our data across panels and the Baltagi LMtest shows that there is serial correlation as well. We thus use the OLS and fixed-effects methods to adjust the standard errors for intragroup correlation, thus making the results robust to heteroscedasticity and serial correlation. The GMM method also controls for heteroscedasticity and we test the presence of serial correlation of order one and two. To develop the 2SLS method for the economic growth regressions, we use the approach developed by Driscoll and Kraay (1998) that guarantees that the covariance matrix estimator is consistent, independently of the cross-sectional dimension, in contrast to Parks-Kmenta and the Panel-Corrected Standard Errors (PCSE) 
CART analysis to search for the presence of economic growth regimes. The CART analysis identifies subgroups of countries that obey a common linear growth model based on neoclassical variables.

We identify four subgroups according to three different cut-off points by order of relevance, which are 2.75 and 1.29 for investment in physical capital and -2.47 for population growth rates. The respective subgroups are "invest $<1.29$ " with 13 observations, "1.29 $\leq$ invest $<2.75$ " with 143 observations, "invest $\geq 2.75$ and population $<-2.47$ " with 610 observations, and "invest $\geq 2.75$ and population $\geq-2.47$ " with 25 observations. To test the robustness of these results, we separate the data according to the subgroups and test the hypothesis that all the countries follow the same convergence dynamics independently of the subgroup to which they belong.

Unfortunately, we are unable to compare subgroups according to the CART cut-off points since the number of observations is insufficient in two of the four sub-samples. ${ }^{21}$ To overcome this problem, for the most appropriate variable in the CART analysis given the sub-groups sample sizes, invest, we select a cut-off point at the median value $3.10 .^{22}$ This choice enables us to have over 350 observations in each of the two sub-samples, which are sufficient to verify whether or not there is presence of multiple economic growth regimes.

Table A.5 in the appendix reports the mean values of the neoclassical variables initial income, income_ini, population growth rates, popu., investment in physical capital, invest, and schooling, scho., according to the CART and the median cut-off points in the investment in physical capital variable, invest. We can see from this table that there are no large differences in neoclassical variables when separating the sample according to the CART and median cutoff points. We therefore explore whether or not there is evidence of the presence of two economic growth regimes after accounting for variation in structural characteristics. These results are shown in Table A.6 given in the appendix.

This table reports mean values of the convergence rate, $\lambda$, associated with the independent variables coefficients' estimates of equation (6) according to four estimation methods, namely, OLS, fixed-effects, DIF-GMM, and SYS-GMM. It also reports the number of observations actually used, Observations, the Fisher and Wald statistics, $F$ and Wald, that test the joint significance of the coefficients associated with the dependent and the independent variables, the Hansen statistic with the p-value in parentheses, Hansen, that tests the validity of the instruments used, the first- and second-order autocorrelation coefficients of the residuals in first differences, $m_{1}$ and $m_{2}$, and the Chow test, Chow, that tests the null hypothesis that the coefficients of the two sub-samples are equal and hence that there is only a single economic growth regime. In the DIF-GMM estimation, we use the variable french in levels as an additional instrument variable. In SYS-GMM, we use the variables colonial and french in levels as instruments for the equation in first differences. ${ }^{23}$

The results of the Chow test show the presence of two economic growth regimes according to the OLS and fixed-effects methods. This is consistent with has been reported in the empirical literature (Durlauf et al., 2005). Our global convergence rates are also close to

approaches, which typically become inappropriate when the cross-sectional dimension of a microeconometric panel gets large.

${ }^{21}$ With fewer than 5 cases per group and fewer than 50 groups, standard errors for fixed effects will be too small (increased Type I errors) and random effects variances and their standard errors may be underestimated (Hox 2002; Hox 2010).

${ }^{22}$ The regression tree shows a preference for investment in physical capital to separate the sample. This suggests that investment in physical capital dominates the other variables in identifying multiple regimes in the data.

${ }^{23}$ The DIF-GMM and SYS-GMM methods generate instruments that grow quadratically with $T$, which can bias the estimates when the number of instruments is too large with respect to the number of observations. The weakness of specification tests is a particular concern for the SYS-GMM method whose instruments are only valid under nontrivial assumptions. We should hence take a conservative p-value of the Hansen test (Roodman, 2009). 
those typically estimated in the literature, which generally lie between 2 and 3\% (Barro and Sala-i-Martin, 1992). We can also observe in Table A.6 that, as expected, OLS and fixedeffects estimates are biased in opposite directions. Moreover, when dividing the sample according to the cut-off point in investment in physical capital, we find that the rate of convergence is higher for those countries with higher rates of investment than those with lower rates of investment.

From Table A.6 we can also see that the estimates of the convergence rate for the DIFGMM method do not lie between OLS and fixed-effects estimates. As in Caselli et al. (1996), this questions the validity of the DIF-GMM method. The SYS-GMM method is likely to be more robust in the presence of highly persistence series effects. Indeed, the estimates of the convergence rate for the SYS-GMM method stand between OLS and fixed-effects estimates. Besides, we can see from Table A.6 that there is compliance with the SYS-GMM assumptions. There is no second-order serial autocorrelation. In addition, the Hansen test accepts the validity of the instruments.

Table A.7 gives the summary statistics above and below the median cut-off point in investment in physical capital for the variables that we use in our growth regressions. When comparing the two sub-samples, we see that the ratio of renewable natural capital in wealth is larger for countries with investment in physical capital below the median cut-off point than for countries with investment in physical capital above the median cut-off point. Otherwise, the most significant differences between the sub-samples with the investment values in physical capital above and below the median cut-off point are those associated with initial income, fertility rate, openness, inflation, Sub-Saharan Africa, ethnic tensions, and institutional endowments $(k k z 96)$.

In Tables A.8 and A.9, we present the correlation matrix between the proximate theories' variables and the variables associated with the fundamental theories when the level of the correlation coefficient is greater than or equal to 0.40 for the sub-samples above and below the median cut-off point in investment in physical capital. The proxy variables associated with four fundamental theories, namely, the religion, the natural capital (renewable), the fractionalization, and the institutions theories turn out to be strongly correlated with variables from every proximate theory except for the macroeconomic policy theory. In particular, for the sub-sample above the median cut-off point in investment in physical capital, the share of renewable natural capital is correlated with the demography proximate theory (fertility and life expectancy variables). For the sub-sample below the median cut-off point in investment in physical capital, the share of renewable natural capital is correlated with neoclassical (population growth rates), demography (fertility), regional heterogeneity (Sub-Saharan Africa) proximate theories Building on these results, we analyze whether or not the fundamental theories just mentioned, religion, renewable natural capital, fractionalization, and institutions have some explanatory power in the growth regressions, beyond the influence exerted through proximate theories' variables.

On the basis of the CART model, we find evidence of the existence of multiple economic growth regimes depending on the median level of investment in physical capital. According to this result, the economic growth regressions are developed for the whole sample and for the two sub-samples defined by the cut-off point in the median level of investment in physical capital, which determines the two economic growth regimes. We find that the ratio of renewable natural capital in wealth is larger for countries with investment in physical capital below the median cut-off point than for countries with investment in physical capital above the median cut-off point (see Table A.7).

Moreover, the share of renewable natural capital in wealth is correlated with neoclassical (population growth rates), demography (life expectancy and fertility rate) and regional heterogeneity (Sub-Saharan Africa) proximate theories (see Tables A.4, A.8, and A.9). Besides 
renewable natural capital, other fundamental theories such as the religion, the fractionalization and the institutions theories are also correlated with proximate theories. We further explore this point in the next section by analyzing whether or not the proxy variables of these fundamental theories directly impact economic growth beyond the influence that may be indirectly exerted through proximate theories.

\section{BMA Estimation Results}

In this section, we discuss the estimation results of the regressions specified in equation (1) with the aim of evaluating the relative merits of the different growth theories considered in this paper. Tables A.10 through A.18 in the appendix show the results of the estimation of the growth regressions under the BMA specification with model uncertainty. The dependent variable is the average growth rate of real per capita GDP corresponding to 10 five-year periods from 1960 to 2009 for 83 countries. In the context of the BMA framework, a specific theory is satisfactory if the posterior mean of its probability is at least as large as twice the posterior standard deviation. ${ }^{24}$ In Tables A.10-A.18, the symbol "\#" denotes the posterior inclusion probability of each theory and this probability is marked in bold when such a theory is a relatively robust determinant of economic growth, i.e., when the variables used to proxy it are jointly significance, with robustness increasing as the probability gets close to one.

Following Durlauf et al. (2008a), we use as instruments for endogenous right-hand-side variables previous values or even initial values when available, with the exception of inflation, religion shares, and natural capital, and use their without uncertainty Two-Stage Least Squares (2SLS) fitted values. For inflation, we use as instruments the colonial dummy for Spain or Portugal colony, British, and French legal origins. For religion shares, we use the corresponding shares in 1900 and, following van der Ploeg and Poelhekke (2010), we use a dummy for the existence of a presidential system and mineral resource stocks as instruments for natural capital variables. ${ }^{25}$

In the remainder of the article, we do not distinguish between the two types of natural capital measures, i.e., natural capital in share of wealth or per capita terms. We first evaluate the performance of the natural capital theory, then the other new growth theories, and finally the neoclassical theory. To improve the interpretation of our results, we end this section with an exploration of how natural capital is related to the standard variables affecting economic growth, namely, income per capita, income inequality, human well-being, especially human development, and institutional quality. The results on the natural capital theory are given in Tables A.10, A.11, and A.12, those on renewable natural capital in Tables A.13, A.A14, and A.15, and those on non-renewable natural capital in Tables A.16, A.17, and A.18. The BMA estimation results are given in Tables A.10, A.13, and A.16 for the full sample and in Tables A.11-A.12, A.14-A.15, and A.17-A.18 for the two sub-samples defined by the cut-off point in the median level of investment in physical capital represented by the variable invest. Table 2-5 summarize our results.

Table A.10-A.18 show results when we include both proximate and fundamental determinants in the model space in columns 1,2 , and 3 as well as when only fundamental growth determinants are in the model space in columns 4, 5, and 6 . As to columns 1 and 4, they give the value of the posterior probability that each theory belongs to the "true" model according to the BMA estimation method. Tables A.10 through A.18 report our findings on the "robustness" of a given theory where robustness refers to the ability of the variables used as proxies for this theory to predict economic growth. More specifically, we test the joint

\footnotetext{
${ }^{24}$ See Brock and Durlauf (2001).

${ }^{25}$ The 2SLS regression results are very similar to the BMA estimation results with uncertainty and the results are available from the authors upon request.
} 
economic significance of the variables used to proxy that theory in the regressions. ${ }^{26}$ In the context of the BMA estimation framework, a specific theory is satisfactory if the posterior mean of its probability is at least as large as twice the posterior standard deviation (see Brock and Durlauf, 2001). ${ }^{27}$

\section{The Natural Capital Theory}

Table 2 below provides summary results on the natural capital theory. The results are reported for the aggregated renewable and non-renewable natural capital variables, separately for the renewable and non-renewable natural capital variables, and each for the full sample and the sub-samples defined by the median cut-off point in investment in physical capital, invest. The posterior inclusion probability of a theory is marked in bold to signify that this theory is robust in explaining economic growth as reflected in the significance of its proxy variables shown in Tables A.10-A.18.

From the results shown in Table 2 and Tables A.10-A.18, it appears that natural capital is not a robust determinant of economic growth when we consider both proximate and fundamental theories. These findings contradict previous ones by Ding and Field (2005), Cerny and Filer (2007), and Gylfason (2011). When we consider only fundamental growth theories, renewable natural capital becomes relatively robust. Thus, such a capital affects indirectly economic growth through its influence on proximate theories' proxy variables. Our results therefore indicate that the reason why previous findings on the direct contribution of natural capital to economic growth, based on standard methods that do not account for model uncertainty, are fragile.

Our preliminary analysis of the data has shown (see Table A.9) that, as a fundamental theory, the share of renewable natural capital in wealth is correlated with neoclassical (population growth rates), demography (fertility rate) and regional heterogeneity (Sub-Saharan Africa) proximate theories. Moreover, concerning the BMA regressions, fertility is a robust determinant of growth and negatively correlated with it. Consequently, we infer that the share of renewable natural capital in wealth contributes to economic growth indirectly through fertility rates. Indeed, when the demography variables are included in the model space that has only fundamental theories, the renewable natural capital theory that is found to be robust in explaining economic growth (see column 4 of Table 2 and the value of 0.605 as a value for its posterior inclusion probability) is not longer relevant as its posterior probability falls to 0.174 , while the posterior probability of the demography theory is equal to $1 .{ }^{28}$

\footnotetext{
${ }^{26}$ Note that the variables used as proxies for a theory may not be individually yet jointly significant. Given that the ratio of the number of observations to that of the independent variables should not fall below 5 (Bartlett et al., 2001), as in Durlauf et al. (2005), we exclude from the BMA regressions the variables that have weak explanatory power in our regressions compared to those presented in Table A.3, namely, the religion variables corresponding to Buddhism, Catholicism, Judaism, and Orthodox religion. Checking for multicollinearity leads us to further exclude some additional variables, which are the regional heterogeneity variables East Asia and the Pacific and the institutional variables Liberal democracy, Public sector corruption, Legal formalism: Check (1), Legal formalism: Check (2), and Complex.

${ }^{27}$ Note that within the BMA context, we no longer can appeal to the standard 10, 5, and $1 \%$ statistical significance levels or the p-values.

${ }^{28}$ These results are available from the authors upon request.
} 
Table 2. Determinants of economic growth: BMA posterior inclusion probability results for the natural capital theory

\begin{tabular}{|c|c|c|c|c|c|c|}
\hline \multirow[b]{2}{*}{ Type } & \multicolumn{3}{|c|}{$\begin{array}{l}\text { Proximate and } \\
\text { fundamental theories }\end{array}$} & \multicolumn{3}{|c|}{ Fundamental theories } \\
\hline & $\begin{array}{l}\text { Full } \\
\text { sample }\end{array}$ & $\begin{array}{l}\text { invest } \geq \\
3.10\end{array}$ & $\begin{array}{l}\text { invest }< \\
3.10\end{array}$ & $\begin{array}{l}\text { Full } \\
\text { sample }\end{array}$ & $\begin{array}{l}\text { invest } \geq \\
3.10\end{array}$ & $\begin{array}{l}\text { invest }< \\
3.10\end{array}$ \\
\hline Natural capital & 0.250 & 0.170 & 0.096 & 0.227 & 0.084 & 0.341 \\
\hline Natural capital (renewable) & 0.168 & 0.165 & 0.220 & 0.605 & 0.378 & 0.525 \\
\hline Natural capital (non-renewable) & 0.277 & 0.153 & 0.079 & 0.059 & 0.038 & 0.124 \\
\hline
\end{tabular}

\section{The Other New Growth Theories}

Beyond the role of renewable natural capital as a share of wealth, other variables representing new growth theories such as demography, religion, and institutions can also have an impact on economic growth as can be seen from Tables 3 below, which is has the same structure as Table 2 above, and and Table A.10. In fact, with the exception of the natural capital theory findings, the BMA analysis of the remaining determinants of economic growth yield results that are very similar when including in the estimation natural capital variables (see Tables A.10, A.11, and A.12), and renewable (see Tables A.13, A.15, and A.15) and non-renewable natural capital variables (see Tables A.16, A.17, and A.18). Compared to the results on the natural capital theory in Table 2, Table 3 doesn't show a robust impact of the renewable natural capital theory on economic growth as in this table we are reporting the sum of renewable and non-renewable natural capital variables. As in Barro (1991; 1996; 1997) and Barro and Lee (1994), fertility seem to be significantly detrimental to economic growth (see Table A.10). In terms of religion, the eastern religion favors economic growth both directly and indirectly (see Table 3), thus confirming previous results in the empirical literature (Barro and McCleary 2003; Durlauf et al. 2008a).

Our results suggest a negative impact of the quality of institutions on economic growth, both directly and indirectly, considering only fundamental theories (see Tables 3 and A.10), which contradicts Acemoglu et al. (2002). A possible interpretation of this result is that weaker checks and balances may enhance economic growth by facilitating policy decision making (Barro, 1994). Another reason for this somewhat counter-intuitive result is that our measure of institutional quality is positively correlated with political instability, a variable for which there is significant evidence in the empirical literature of a negative relationship with respect to economic growth. On this point, see Barro (1991), Barro and Lee (1994), Sachs and Warner (1995), Alesina et al. (1996), and Caselli et al. (1996), among others. ${ }^{29}$

Fractionalization turns out to matter for economic growth only when fundamental growth theories are considered as can be seen from Table 3 and this result might be viewed as contributing to explaining with additional precision previous analyses in the empirical literature that suggest that fractionalization plays an important role in growth (Easterly and Levine 1997; Alesina et al. 2003). Moreover, when we include the demography variables in the model space only with fundamental theories, the fractionalization variables that were found to be robust determinants as can be seen from column 4 of Table 3 where the posterior probability of the theory that these variables are proxies for is equal to 0.964 are no longer relevant, the posterior probability plunging to $0.06 .^{30}$ This is consistent with our preliminary results where we found that fractionalization is correlated with neoclassical (population growth rates), demography (fertility rate), and regional heterogeneity (Sub-Saharan Africa) variables (see Table A.4). As

\footnotetext{
${ }^{29}$ Our executive constraints variable reflects the outcomes of most recent elections (Glaeser et al. 2004). Cox and Weingast (2018) find that the quality of legislatures measured by the executive's horizontal accountability is more important than the existence of free and fair elections for economic growth.

${ }^{30}$ The results are available from the authors upon request.
} 
with the natural capital theory, our results indicate that previous findings on the importance of fractionalization to economic growth are somewhat fragile.

Table 3 Determinants of economic growth: BMA posterior inclusion probability results for the other new growth theories

\begin{tabular}{lllllll}
\hline \hline & \multicolumn{3}{c}{$\begin{array}{c}\text { Proximate and } \\
\text { fundamental theories }\end{array}$} & \multicolumn{2}{c}{ Fundamental theories } \\
\cline { 2 - 7 } Theory & Full & \multicolumn{2}{c}{ invest $\geq$ invest $<$} & Full & invest $\geq$ & invest $<$ \\
& sample & 3.10 & 3.10 & sample 3.10 & 3.10 \\
Demography & $\mathbf{1 . 0 0 0}$ & $\mathbf{1 . 0 0 0}$ & 0.161 & & & \\
Macroeconomic policy & 0.028 & $\mathbf{0 . 9 7 3}$ & 0.041 & & & \\
Regional heterogeneity & 0.085 & 0.002 & 0.384 & & & \\
Religion & $\mathbf{0 . 9 8 1}$ & $\mathbf{0 . 9 8 0}$ & 0.241 & $\mathbf{1 . 0 0 0}$ & $\mathbf{1 . 0 0 0}$ & 0.116 \\
Natural capital & 0.250 & 0.170 & 0.096 & 0.227 & 0.084 & 0.341 \\
Geography & 0.056 & 0.078 & 0.065 & 0.035 & 0.037 & 0.088 \\
Fractionalization & 0.056 & 0.092 & 0.052 & $\mathbf{0 . 9 6 4}$ & $\mathbf{0 . 9 9 2}$ & 0.083 \\
Institutions & $\mathbf{1 . 0 0 0}$ & $\mathbf{1 . 0 0 0}$ & $\mathbf{0 . 9 9 9}$ & $\mathbf{1 . 0 0 0}$ & $\mathbf{0 . 9 9 9}$ & $\mathbf{1 . 0 0 0}$ \\
\hline
\end{tabular}

\section{The Neoclassical Theory}

In contrast with the findings of previous studies, including, Barro (1991), Barro and Lee (1994), Sachs and Warner (1995), Barro (1996), Caselli et al. (1996), and Barro (1997), among others, we find that investment in physical capital is not a significant determinant of economic growth. The effect of schooling is not significant either, but this result remains largely consistent with what is found in the empirical literature (Durlauf et al., 2008a). In the instance where we drop the demography theory from the model space, we find that population growth is negatively, though still not significantly, related to economic growth as in Mankiw et al. (1992), Kelley and Schmidt (1995), and Bloom et al. (1998). ${ }^{31}$ This variable becomes significant for the sub-sample with investment in physical capital below the median cut-off point (see Tables A.11, A.14, and A.17).

In Table A.10, we see that there is robust empirical evidence of conditional convergence, with a negative and significant coefficient for the initial income variable, as found in many previous studies, including, Barro (1991), Sachs and Warner (1995), Barro (1997), and Easterly and Levine (1997), among others. Our findings are overall consistent with those of the conditional convergence literature as well as with previous studies based on BMA estimation methods.

\section{Multiple Growth Regimes}

Since there is evidence that there are different economic growth regimes depending on the level of investment in physical capital, we compare the two sub-samples according to the median level of such an investment. We find two main differences between these two sub-samples. Above the median cut-off point, in addition to demography, religion, and institutions, macroeconomic policy is a robust determinant of economic growth. In particular, we see from Table A.11 that inflation has a negative and significant impact on economic growth, a result that is consistent with the findings of the empirical literature (Barro 1997; Bruno and Easterly 1998). Below the median cut-off point, however, the only robust explanatory theory of growth is the one based on institutions, although no specific institutional variable emerges as significant (see Table A.12).

\footnotetext{
${ }^{31}$ The results are available from the authors upon request.
} 
Most importantly, natural capital remains a non-robust determinant of economic growth when separating the countries in the sample according to the median level of investment in physical capital. We also test for the impact of renewable and non-renewable natural capital on economic growth when we allow for the possibility of alternative growth regimes to the one defined by investment in physical capital. We focus on income per capita, income inequality, human development, and institutional quality to distinguish different growth regimes while analyzing the role of natural capital in economic growth. An explanation of the choice of these variables in order to distinguish growth regimes is in order.

Richer countries may be specialized in services and/or be wealthy enough to protect their natural resources and import them from poorer countries, and thus, under these circumstances, may depend loosely on their local (renewable) natural capital. Singapore, The Netherlands, Japan, and Switzerland, for instance, import most of their food. Since international trade allows for such a specialization, highly polluting activities can be displaced to poor countries (Lenzen et al., 2012). This specialization may also depend on the country's history, whether or not it is an ancient colony, especially when there are easily exportable and controllable products such as oil and diamonds rather than cereals for example (Pomeranz 2000).

Income inequality within countries could also matter since different social groups might be affected in different ways by the loss of natural capital. In particular, the groups who benefit more from economic growth are not necessarily those who are more affected by natural capital degradation (TEEB 2008). Such a context has been often associated with the granting of perverse subsidies (Edenhofer, 2015). Thus, we should distinguish the dependence on local (renewable) and on global (non-renewable) natural capital depending on within country income inequality. In addition, human development might be an appropriate indicator to examine human dependence on natural capital as it takes into account health, among other social effects of natural capital. The inverse relationship between dependence on natural capital and education has also been explored (Gylfason, 2001). Furthermore, the negative relationship between natural resource intensity and economic growth can depend on institutional quality (Melhum et al. 2006; Torvik 2009; Boschini et al. 2013).

Table 4 shows our results on the natural capital theory when running the full model with eight theories as in Table 2. We present the summary findings of the BMA posterior inclusion probability results for the aggregated renewable and non-renewable natural capital variables, and for renewable and non-renewable natural capital variables separately. As in Table 2, we separate the sample according to the levels of investment in physical capital, but we also divide it according to income per capita, income inequality, human development, and institutional quality median values under the hypothesis that there are different growth regimes. ${ }^{32}$ Based on these additional country typologies, we find a direct positive impact of natural capital on economic growth in the sub-sample with lower income inequality, since it significantly impacts growth when analyzing proximate and fundamental theories together. ${ }^{33}$

Besides, as can be seen from Table 4, when we analyze separately renewable and nonrenewable natural capital, we find that that the share of renewable natural capital in wealth is positively correlated with fertility in the sub-sample with higher levels of human development and, in turn, we have found that fertility affects negatively economic growth. In contrast with

\footnotetext{
${ }^{32}$ An ex-post exploration of the data, following the procedure of the preliminary analysis (see Table A.6), shows that we cannot reject the presence of different growth regimes for the sub-samples based on income per capita (under a fixed-effects estimation with the $\mathrm{F}$ statistic significant at the $1 \%$ statistical level), income inequality (under OLS and fixed-effects estimations both with the F statistic significant at the 1\% level), human development (under OLS and fixed effects estimations both with the F statistic significant at the 1\% level), and institutional quality (under a fixed-effects estimation at with the $\mathrm{F}$ statistic significant at the $1 \%$ level). These results are available from the authors upon request.

${ }^{33}$ The results are available from the authors upon request.
} 
the effects of the share of renewable natural capital in wealth, the share of non-renewable natural capital in wealth has a direct impact on economic growth. These results hold for two different sub-samples, namely, those characterized by lower income inequality and by higher institutional quality, given that natural capital is a robust determinant of growth when both proximate and fundamental theories are analyzed together. This impact is positive through the variable non-renewable natural capital in wealth in both sub-samples and significant in the subsample characterized by higher institutional quality.

Table 4 Natural capital components as determinants of economic growth according to different country typologies

\begin{tabular}{|c|c|c|c|c|c|c|}
\hline \multirow[b]{2}{*}{ Typology } & \multicolumn{4}{|c|}{ Proximate and fundamental theories } & \multicolumn{2}{|c|}{ Fundamental theories } \\
\hline & Total & Renewable & $\begin{array}{c}\text { Non- } \\
\text { renewable }\end{array}$ & Total & Renewable & $\begin{array}{c}\text { Non- } \\
\text { renewable }\end{array}$ \\
\hline Full model & 0.250 & 0.168 & 0.277 & 0.277 & 0.605 & 0.059 \\
\hline Investment in physical capital & & & & & & \\
\hline invest $<3.10$ & 0.096 & 0.220 & 0.079 & 0.341 & 0.525 & 0.124 \\
\hline invest $\geq 3.10$ & 0.170 & 0.165 & 0.153 & 0.084 & 0.378 & 0.038 \\
\hline Income per capita & & & & & & \\
\hline income $<9$ & 0.089 & 0.061 & 0.085 & 0.448 & 0.159 & 0.174 \\
\hline income $\geq 9$ & 0.073 & 0.193 & 0.193 & 0.152 & 0.315 & 0.070 \\
\hline Income inequality & & & & & & \\
\hline GINI $<38.61$ & 0.701 & 0.273 & 0.802 & 0.164 & 0.186 & 0.329 \\
\hline$G I N I \geq 38.61$ & 0.079 & 0.096 & 0.062 & 0.079 & 0.056 & 0.090 \\
\hline Human development & & & & & & \\
\hline$H D I<0.628$ & 0.084 & 0.099 & 0.074 & 0.239 & 0.066 & 0.326 \\
\hline$H D I \geq 0.628$ & 0.042 & 0.206 & 0.451 & 0.052 & 0.732 & 0.121 \\
\hline Institutional quality & & & & & & \\
\hline$k k z 96<0.07$ & 0.087 & 0.056 & 0.079 & 0.098 & 0.093 & 0.060 \\
\hline$k k z 96 \geq 0.07$ & 0.124 & 0.383 & 0.930 & 0.043 & 0.187 & 0.353 \\
\hline
\end{tabular}

The Relationship between Natural Capital and other Determinants of Growth

Finally, to further interpret our results, we investigate the issue of how natural capital is related to the different variables affecting economic growth, namely, income per capita, income inequality, human well-being, especially human development, and institutional quality. Table 5 shows the results. This table reports mean values of natural capital theory variables. The classification of countries is done according to median values of investment in physical capital, income per capita, income inequality, human development, and institutional quality. Income per capita is the logarithm of GDP per capita, higher values of the GINI indicator indicate higher income disparities, and higher values of HDI (Human Development Index) indicate higher human development. The institutional quality indicator is proxied by the variable $k k z 96$ (see Table A.2) with higher value implying higher institutional quality, and the observation unit corresponds to a time-series-cross-sectional data point.

There are two major points to highlight. First, countries with higher income per capita, higher human development, and higher institutional quality have higher renewable and nonrenewable natural capital per capita. ${ }^{34}$ Such a result is consistent with our hypothesis that renewable natural capital is very necessary for the quality of life and hence is of primary concern to wealthy, equitable, and empowered countries. Concerning non-renewable natural capital, our suggestion is that well empowered countries manage more efficient technologies to

\footnotetext{
${ }^{34}$ The results concerning the variable inequality are not unambiguous.
} 
extract costly natural resources, with a preference for a large degree of autonomy, although they are more dependent due to their higher consumption rate of such resources (Chen et al. 2011). ${ }^{35}$

Second, regarding these same indicators, namely, income per capita, human development, and institutional quality, renewable natural capital in wealth and per capita have an inverse ranking. Indeed, countries with higher income per capita, lower income inequalities, higher human development, and higher institutional quality have higher renewable natural capital per capita but lower renewable natural capital in wealth. As already stated, there is a large empirical literature explaining the negative relationship between natural capital dependence and economic growth. The results on renewable natural capital per capita can be linked to the empirical analyses developed by Gylfason (2011), whereby some countries somehow succeed in maintaining a larger availability of natural capital in per capita terms. Further exploration of such differences are needed. In particular, it seems important to further investigate the results on the inverse ranking when correlating natural capital in wealth and per capita, with income per capita, income inequality, and human development, that hold true only for renewable natural capital, not for non-renewable, which is, to our knowledge, an original result.

Table 5 Characterization of countries according to different typologies ${ }^{+}$

\begin{tabular}{|c|c|c|c|c|c|c|c|}
\hline \multirow[b]{2}{*}{ Typology } & \multirow[b]{2}{*}{ Obs. } & \multicolumn{3}{|c|}{ Natural capital in wealth } & \multicolumn{3}{|c|}{ Natural capital per capita } \\
\hline & & Total & Renewable & $\begin{array}{c}\text { Non- } \\
\text { renewable }\end{array}$ & Total & Renewable & $\begin{array}{c}\text { Non- } \\
\text { renewable }\end{array}$ \\
\hline \multicolumn{8}{|l|}{ Income per capita } \\
\hline income $<9$ & 479 & 0.35 & 0.29 & 0.06 & 8 & 7 & 1 \\
\hline income $\geq 9$ & 351 & 0.14 & 0.06 & 0.08 & 32 & 13 & 19 \\
\hline \multicolumn{8}{|c|}{ Income inequality } \\
\hline GINI $<38.61$ & 320 & 0.15 & 0.15 & 0.01 & 16 & 11 & 3 \\
\hline$G I N I \geq 38.61$ & 510 & 0.33 & 0.23 & 0.10 & 21 & 8 & 13 \\
\hline \multicolumn{8}{|c|}{ Human development } \\
\hline$H D I<0.628$ & 322 & 0.44 & 0.38 & 0.08 & 7 & 6 & 1 \\
\hline$H D I \geq 0.628$ & 500 & 0.16 & 0.10 & 0.07 & 26 & 12 & 14 \\
\hline \multicolumn{8}{|c|}{ Institutional quality } \\
\hline$k k z 96<0.07$ & 410 & 0.38 & 0.29 & 0.09 & 11 & 6 & 5 \\
\hline$k k z 96 \geq 0.07$ & 420 & 0.14 & 0.10 & 0.04 & 26 & 13 & 13 \\
\hline
\end{tabular}

${ }^{+}$Natural capital per capita is expressed in 2000,000.00 USD.

\section{Conclusion}

This article contributes to the empirical literature on the determinants of economic growth by focusing on the role of natural capital, distinguishing its renewable and non-renewable forms, and shedding light on the mechanisms through which this role is exerted. We use a dataset on 83 countries covering the 1960-2009 period to estimate reduced-form growth regressions encompassing a set of proximate and fundamental growth theories with the objective of evaluating the relative explanatory power of these theories. More specifically, we apply the BMA approach that accounts for model uncertainty to test the statistical significance of the various variables used to proxy these theories, paying special attention to the natural capital theory. We thus distinguish renewable natural capital and non-renewable natural capital and explore both direct and indirect impacts on economic growth. We also subdivide our data

\footnotetext{
${ }^{35}$ It is worth noting that the relationship between natural capital and income growth and income is complex. For instance, some OPEC countries have very high-income levels per capita, mainly linked to the oil sector, but have experienced a negative real growth over the past few decades.
} 
sample based on threshold values of investment in physical capital and allow for the existence of multiple growth regimes in the data. The main results obtained are the following.

When using the whole sample in the BMA estimation and assuming a unique growth regime, we find that the natural capital theory, as reflected in natural capital dependence, proxied by share of natural capital in wealth, and natural capital abundance proxied by natural capital per capita, is not a robust direct explanatory theory of growth, i.e., such proxy variables do not have a direct significant impact on economic growth proxied by GDP per capita rate of growth. These results come in contrast with previous results found with standard methodologies that do not explicitly account for model uncertainty. ${ }^{36}$ Interestingly enough though, we find that the share of renewable natural capital in wealth affects economic growth negatively and indirectly through its influence on proximate theories proxy variables, more specifically, through its effect on fertility. Thus, a natural capital dependence detrimental effect on economic growth seems to finds its way through demography.

Concerning the new theories of growth, namely, those that emphasize demographic, religious, and institutional factors, we find that they are robust in explaining economic growth when the BMA estimation methodology is utilized. In addition, the macroeconomic policy theory is found to provide a satisfactory direct explanatory framework for economic growth when the sub-sample with investment in physical capital above the median cut-off point is used. As to the theory based on fractionalization, it also explains economic growth, but, when we use the sub-sample with investment in physical capital above the median cut-off point, on the one hand, and the explanation is indirect and passes through proxies of the demography theory, on the other hand. We had difficulties to identify some robust determinants of economic growth when using the sub-sample corresponding to values of investment in physical capital below the median cut-off point. In fact, the only proxy variables that turn out to be significant are those of the religion theory, thus suggesting that they are the only relevant direct determinants of economic growth. ${ }^{37}$

Returning to the share of renewable natural capital in wealth, it has a rather indirect impact on economic growth that we uncover when we allow for the presence of multiple growth regimes and when only fundamental theories alone are examined. In particular, we find an indirect negative impact through human development and, more precisely, through fertility rates. ${ }^{38}$ In contrast, we find a direct positive impact of the share of non-renewable natural capital in wealth on economic growth when exploring proximate and fundamental theories together in the sub-samples corresponding to lower income inequality and higher institutional quality. ${ }^{39}$ This result may reflect the role of capital accumulation in the domestic economy as capacity constraints are relaxed (van der Ploeg and Venables 2013).

A striking feature of our analysis is the lack of evidence of a strong impact of renewable natural capital on economic growth. Several reasons may explain this finding. First, the quality of data might be of concern, in particular, because some important data are poorly integrated in

\footnotetext{
${ }^{36}$ See Ding and Field (2005), Cerny and Filer (2007), and Gylfason (2011), among others.

37 Such a negative result raises the question of some variables possibly being omitted from our empirical framework, which certainly deserves further investigation efforts.

${ }^{38}$ The natural capital dependence effect and, when considering long-term horizons, the decrease of human capital, the capital shallowing (Solow 1956) and the congestion of fixed resources (Malthus 1798) effects seem to be the most relevant hypotheses through which the role of fertility in economic growth can be examined (Ashraf et al. 2013). The "Dutch disease" argument, according to which the over-development of a natural resource sector affects negatively the overall economy, could also be invoked to explain low economic growth in countries where the share of renewable natural capital in wealth is very high (Bruno and Sachs 1982).

${ }^{39}$ We have omitted to take into account the numerous complementarities between the different sub-components of the variable natural capital, as this would not be relevant for exploring the separate role of each of these subcomponents in explaining the final results of our analysis.
} 
natural capital accounts. ${ }^{40}$ Indeed, variations in land uses do not usually include biological diversity losses, which depend on land-use intensity, human population density, and road proximity (Newbold et al. 2016). The degradation of renewable natural capital productivity, which can be very high and also varies greatly across countries (Sutton et al. 2016), should be also taken into account. Examining such an effect might be particularly important since the loss in terms of crossing biodiversity safe plenary limits would concern $58 \%$ of terrestrial areas where more than $70 \%$ of humans live. In addition, as indicated in section 4 , there are limitations associated with our data on natural capital based on World Bank (2006) that have been pointed out in the literature (van der Ploeg 2010; van der Ploeg and Poelhekke 2010). Including time-varying data on natural capital and relaxing constraints on interest rates, cost of extraction and time horizons to exhaustion, would be particularly relevant for further testing the robustness of our results.

Second, even though our analysis has shed some light on some important aspects of the functioning of the natural capital-economic growth nexus, in particular, through its direct and indirect channels, more complex investigations should be developed. It seems particularly necessary, in view of the results that we have reached in this article, in particular, on the indirect impacts of natural capital components, to incorporate in the analysis the relationships among a variety of spatial and temporal variables. Indeed, highlighting these relationships, not only the correlations but also possible causal relationships, will help clarify the role of natural capital, because different components of natural capital can affect economic growth though different spatial and temporal effects. This is the case, for instance, of cropland that has an immediate and local effect, whereas protected areas are supposed to have delayed and more global benefits.

Third, it has been argued in the literature that the impact of natural capital on economic growth may also depend on the country sample analyzed and is timeframe. ${ }^{41}$ For instance, Aliyev (2011) reports that the positive impact of share of mining in GDP on economic growth, a proxy for natural resource dependence, that Sala-i-Martin et al. (2004) find for the 1960-1996 period no longer hold for the longer period 1960-2003. Moreover, when we compare our results and those of Durlauf et al. (2008a) using a shorter period of time and a smaller sample of countries, we find different robust determinants of economic growth. ${ }^{42}$ Thus, further work with longer time-series concerning specific samples of countries will enable us to develop a further understanding of the role of natural resources in economic growth. The fact that in our work, as in Konte (2013)'s, we have defined some specific country typologies in order to explore this

\footnotetext{
${ }^{40}$ The quality of data will certainly benefit from initiatives such as the "Ecosystem natural capital accounts" project that considers different kinds of renewable natural capital and offers to keep distinct accounts for water, carbon, and ecosystem infrastructures (Weber 2014). Indeed, developing adequate accounting methods for natural capital so that its different components are properly recorded and integrated into social rules and economic regulation is necessary for the success of policies aimed at improving societal welfare.

${ }^{41}$ See Aliyev (2011) and Lederman and Maloney (2002).

${ }^{42}$ We have indeed compared our results for the period 1960-2009 and those of Durlauf et al. (2008a) for the period 1965-1994. The data used by Durlauf et al. (2008a) concerns 57 countries of which 54 are also present in our work. In particular, both analyses are based on 11 countries from Asia and Oceania, 13 countries from Latin America and Caribbean, 19 countries from North America and Europe and 11 countries from Middle East and Africa. In addition, we include 1 country from Europe, 14 countries from Middle East and Africa, seven countries from Latin America and Caribbean and 7 countries from Asia and Oceania. While Durlauf et al. (2008a) find that among new growth theories, macroeconomic policy is a robust determinant, in our BMA analysis for the full sample we find that demography, religion, and institutions instead are the robust determinants. This suggests that the results are contingent on both the time frame considered and the country sample analyzed.
} 
role raises the question of whether the structuring of these typologies would uncover situations in which countries falling into some given typology would benefit from natural capital. ${ }^{43}$

Finally, there is a need for a broadened view of the role of natural capital in society that goes beyond analyzing its impact on economic growth as it have been traditionally done in the economics profession. ${ }^{44}$ On the one hand, other related socio-economic dimensions such as health, well-being, and quality of life must be given due consideration. On the other hand, the impact of renewable and non-renewable capital on these dimensions, in both wealth and per capita terms, ought to be distinguished in our analyses as they are associated with very different phenomena. Wealth has however typically been ignored and, indeed, one of the primary motivations for the early natural capital accounting efforts in the mid-1980s was the concern that rapid GDP growth in resource-rich countries was achieved through liquidation of natural capital, i.e., a one-off boost to consumption that generated no foundation for sustained improvements in wealth and human well-being. Monitoring wealth, including natural capital, was thus perceived as part of the solution to the challenge of long-term sustainability (Repetto et al. 1989).

The twofold message that our empirical findings convey, namely, that natural capital is an integral part of economic growth and prosperity and as such, must be preserved in developed and more so in developing countries where the stake is higher, and its measurement incorporated in policy decision-making, a necessary condition for the latter being that it be accounting procedures ought to acutely incorpote it, has been heard for the last couple of decades. In this regard, partnership initiatives like The natural capital project under the guidance of the Stanford Advisory Council at Stanford university have been leading the way and ought to be expected and generalized. ${ }^{45}$ Indeed, these initiatives are necessary to guaranty future society resilience to environmental problems and, in order to have a far-reaching impact, should be geared in priority towards developing countries.

The diversity of the relationships between humans and natural capital implies more refined and hence complex policy decisions that are not independent of whether natural capital concerns water, carbon, or ecosystem infrastructures (Weber 2014). Specific policies might have to be conceived, depending on the sort of natural capital concerned and also taking into account their interactions, and geared towards preserving water quality, pollination, flood mitigation, and the like. These types of natural capital involve different people, social groups, and human and ecosystem infrastructures. In this regard, the general trans-cultural framework

\footnotetext{
${ }^{43}$ There exists a lengthy literature seeking to find the characteristics that enable to have a positive relationship between natural capital and economic growth with a special focus on institutional endowments. See Omgba (2015), among others.

${ }^{44}$ On the issue of the social value of natural capital, in particular, its role in fighting poverty, and the need for societies to allocate extremmemly rewarding efforts for recording it, P. Dasgupta states: "Poverty will only be made history when nature enters economic calculations in the same way that buildings, machines, and roads do." (Conservation International 2019). Along similar lines, J. Stiglitz states: "Business is always evaluated by both its income statement and its balance sheet (assets and liabilities, or wealth). Similarly, a prospective homeowner can obtain a mortgage only by demonstrating both his or her income and net assets. Income in any given year can always be made to look good by selling off assets, but liquidating assets undermines the ability to generate income in the future. The true picture of economic health requires looking at both income and wealth. The economic performance of countries, however, is only evaluated based on national income." (World Bank 2006; 2011; 2018) For more on this issue and related ones, see Stiglitz et al. (2009).

${ }^{45}$ See Stanford Advisory Council (2006). This project aims at integrating the value that nature provides to society into major policy decisions. Its objectives are clearly stated as follows: "Our ultimate objective is to improve the well-being of all people and nature by motivating greater and more targeted natural capital investments. Centered at Stanford University, we operate as a partnership between the Chinese Academy of Sciences, the University of Minnesota, the Stockholm Resilience Centre, The Nature Conservancy, and the World Wildlife Fund. We are an interdisciplinary team of academics, software engineers, and real-world professionals all working to make valuing natural capital easier and more accessible to everyone."
} 
formulated around the concept of "Nature contribution to people" (Diaz et al. 2018, IPBES 2019) might help to identify in a systematic way the different sorts of natural capital that matter for socio-economic decisions.

\section{Appendix 1: Data et sources}

The unbalanced panel data set constructed for this study contains observations for 10 five-year periods from 1960 to 2009 on 83 countries from the following regions for which we have data on our variables of interest, namely, neoclassical variables, natural capital in wealth and natural capital per capita:

- Latin America and the Caribbean (20): Argentina, Belize, Bolivia, Brazil, Chile, Colombia, Costa Rica, Dominican Republic, Ecuador, Guyana, Haiti, Honduras, Jamaica, Mexico, Nicaragua, Panama, Peru, Trinidad and Tobago, Uruguay, and Venezuela.

- Middle East and North Africa (10): Bahrain, Brunei, Egypt, Iran, Israel, Jordan, Kuwait, Saudi Arabia, Tunisia, and United Arab Emirates.

- Sub-Saharan Africa (15): Cameroun, Congo, Gabon, Ghana, Kenya, Malawi, Mauritius, Mozambique, Senegal, Sierra Leone, South Africa, Sudan, Uganda, Zambia, and Zimbabwe.

- East Asia and the Pacific (13): Australia, China, Fiji, Indonesia, Japan, Malaysia, New Zealand, Papua New Guinea, Philippines, Republic of Korea, Singapore, Thailand, and Tonga.

- South Asia (5): Bangladesh, India, Maldives, Pakistan, and Sri Lanka.

- North America, Europe and Central Asia (20): Austria, Belgium, Canada, Denmark, Finland, France, Greece, Hungary, Italy, Ireland, Norway, Poland, Portugal, Spain, Sweden, Switzerland, The Netherlands, Turkey, United Kingdom, and United States.

We have collected data on variables regrouped in five categories: neoclassical, demography, macroeconomic policy, regional heterogeneity, religion, natural capital, geography, fractionalization, institutions, and other. The definition of these variables and the data sources are given in Table A.1 below. The choice of the eight new growth theories and the associated variables is largely inspired by the work of Durlauf et al. (2008a). These authors explore the question of what the robust determinants of economic growth are building on 43 growth theories and 145 regressors, each of these theories being statistically significant in at least one study (Durlauf et al. 2005). Besides the eight new growth theories, we also include a category named "Other" to account for some instrument and time dummy-driven growth effects.

Table A.1 Data description

\begin{tabular}{|c|c|}
\hline Designation & Source $(s)$ \\
\hline \multicolumn{2}{|l|}{ Neoclassical } \\
\hline Growth rates of per capita GDP & $\begin{array}{l}\text { Average growth rates (constant } 2005 \text { USD prices) for the } \\
\text { periods } 1960-1964,1965-1969,1970-1974,1975-1979, \\
1980-1984,1985-1989,1990-1994,1995-1999,2000-2004, \\
2005-2009 .\end{array}$ \\
\hline Initial income & $\begin{array}{l}\text { Logarithm of GDP per capita (in constant } 2005 \text { USD prices) in } \\
1960,1965,1970,1975,1980,1985,1990,1995,2000 \text {, } \\
\text { and } 2005 . \text { The instruments for the initial income include the } \\
\text { values in } 1955,1960,1965,1970,1975,1980,1985,1990 \text {, } \\
1995 \text {, and } 2000 .\end{array}$ \\
\hline Population growth rates & $\begin{array}{l}\text { Logarithm of average population growth rates plus } 0.05 \\
\text { for the periods } 1960-1964,1965-1969,1970-1974,1975-1979 \text {, } \\
1980-1984,1985-1989,1990-1995,2000-2004 \text {, and } 2005-2009 \text {. } \\
\text { The instruments for population growth rates include the } \\
\text { average values over } 1955-1959,1960-1964,1965-1969 \text {, }\end{array}$ \\
\hline
\end{tabular}


Investment in physical capital

Schooling
1970-1974, 1975-1979, 1980-1984, 1985-1989, 1990-1995, and 2000-2004.

Logarithm of average ratios over each period of investment in physical capital to GDP for the periods 1960-1964, 1965-1969, 1970-1974, 1975-1979, 1980-1984, 1985-1989, 1990-1995, 2000-2004, and 2005-2009. The instruments for investment include the average values of 1955-1959, 1960-1964, 1965-1969, 1970-1974, 1975-1979, 1980-1984, 1985-1989, 1990-1995, and 2000-2004.

Logarithm of the ratio of male population enrolled in secondary school to total population in $1960,1965,1970$, 1975, 1980, 1985, 1990, 1995, 2000, and 2005.

Demography

Life Expectancy

Reciprocals of life expectancy at age 1 in 1960, 1965, 1970, 1975, 1980, 1985, 1990, 1995, 2000, and 2005.

Fertility rate

The $\log (\mathrm{LN})$ of the total fertility rate in $1960,1965,1970$, $1975,1980,1985,1990,1995,2000$, and 2005.

Macroeconomic policy

Openness

Average ratios for each period of exports plus imports to GDP in 1960-1964, 1965-1969, 1970-1974, 1975-1979, 1980-1984, 1985-1989, 1990-1994, 1995-1999, 2000-2004, 2005-2009. The instruments include the average values of 1955-1959, 1960-1964, 1965-1969, 1970-1974, 1975-1979, 1980-1984, 1985-1989, 1990-1995, and 2000-2004.

Government consumption Average ratios for each period of government consumption to GDP in 1960-1964, 1965-1969, 1970-1974, 1975-1979, 1980-1984, 1985-1989, 1990-1994, 1995-1999, 2000-2004, and 2005-2009.

Inflation

The consumer price inflation rate for the periods 1960-1969, 1970-1979, 1980-1989, 1990-1999, 2000-2009.

Regional heterogeneity Latin America and Caribbean

Sub-Saharan Africa

East Asia and the Pacific

South-East Asia

Religion

Buddhism

Catholicism

Eastern Religion

Hinduism
Dichotomous dummy variable for the region.

Idem.

Idem.

Idem.

Buddhism share in 1970 expressed as a fraction of the Population who expressed adherence to some religion. The instruments include the Buddhism share in 1900 expressed as a fraction of the population who expressed adherence to some religion.

Catholicism share in 1970 expressed as a fraction of the population who expressed adherence to some religion.

The instruments include the catholicism share in 1900 expressed as a fraction of the population who expressed adherence to some religion.

Eastern Religion share in 1970 expressed as a fraction of the population who expressed adherence to some religion.

The instruments include the Eastern religion share in 1900 expressed as a fraction of the population who expressed adherence to some religion.

Hinduism share in 1970 expressed as a fraction of the population who expressed adherence to some religion. The instruments include the Hindu share in 1900 expressed as a fraction of the population who expressed adherence 
Judaism

Islam

Orthodox religion

Protestantism

Other

Natural capital

Natural capital in wealth

Natural capital in wealth (renewable)

Natural capital in wealth (non-renewable)

Natural capital per capita

Natural capital per capita (renewable)

Natural capital per capita (non-renewable)

to some religion.

Judaism share in 1970 expressed as a fraction of the population who expressed adherence to some religion. The instruments include the Jew share in 1900 expressed as a fraction of the population who expressed adherence to some religion. Islam share in 1970 expressed as a fraction of the population who expressed adherence to some religion. The instruments include the Islam share in 1900 expressed as a fraction of the population who expressed adherence to some religion. Orthodox religion share in 1970 expressed as a fraction of the population who expressed adherence to some religion. The instruments include the orthodox religion share in 1900 expressed as a fraction of the population who expressed adherence to some religion.

Protestantism share in 1970 expressed as a fraction of the population who expressed adherence to some religion. The instruments include the protestant share in 1900 expressed as a fraction of the population who expressed adherence to some religion.

Other religion share in 1970. The instruments include the other religion share in 1990.

Time-invariant variable measuring the weight of natural capital in national wealth in 2000 .

Time-invariant variable measuring the weight of renewable natural capital in national wealth (crop, pasture land, timber, non-timber forest resources and protected areas) in 2000. Time-invariant variable measuring the weight of non-renewable natural capital (oil, natural gas, hard coal, soft coal, coal and minerals) in national wealth in 2000.

Time-invariant variable measuring natural capital per capita in 2000. The variable is scaled to take values between zero and one. Time-invariant variable measuring renewable natural capital per capita (crop, pasture land, timber, non-timber forest resources and protected areas) in 2000 . The variable is scaled to take values between zero and one.

Time-invariant variable measuring non-renewable natural capital per capita (oil, natural gas, hard coal, soft coal, coal and minerals) in 2000 . The variable is scaled to take values between zero and one.

\section{Geography}

Coastline Coastline length in $\mathrm{km}$, scaled to take values between zero and one. Landlocked Binary variable where one indicates landlocked country.

Fractionalization

Language

Time-invariant measure of linguistic fractionalization that reflects the probability that two randomly selected individuals from a population belong to different groups. The data ranges from zero to one.

Ethnic group Time-invariant measure of ethnic fractionalization that reflects the probability that two randomly selected individuals from the population belong to different groups. The data ranges from zero to one.

Institutions Liberal democracy
Time variant-index emphasizes the importance of protecting individual and minority rights against the tyranny of the state and the tyranny of the majority. This is achieved 
Public sector corruption

Legal formalism: Check (1)

Legal formalism: Check (2)

Complex

KKZ96

Executive constraints by constitutionally protected civil liberties, rule of law, an independent judiciary, and effective checks and balances that, together, limit the exercise of executive power. To make this a measure of liberal democracy, the index also takes the level of electoral democracy into account. This variable is calculated as the average for the periods 1960-1965, 1965-1970, 1970-1980, 1980-1985, 1985-1990, 1990-1995, 1995-2000, 2000-2005 and 2005-2009. It ranges from zero to one. Higher scores imply a more liberal democracy. Time-variant variables that measures to what extent public sector employees grant favors in exchange for bribes, kickbacks, or other material inducements, and how often they steal, embezzle, or misappropriate public funds or other state resources for personal or family use. This variable is calculated as the average for the periods 1960-1965, 1965-1970, 1970-1980, 1980-1985, 1985-1990, 1990-1995, 1995-2000, 2000-2005 and 2005-2009. It ranges from zero to one. Higher scores imply more corruption.

Time-invariant index of the professionals vs. laymen, written vs. oral elements, legal justification, statutory regulation of evidence, control of superior review, and engagement formalities indices, and the normalized number of independent procedural actions for the case of collection of a check. The index ranges from zero to seven, where seven means a higher level of control or intervention in the judicial process.

Time-invariant index of formality in legal procedures for collecting on a bounced check, rescaled to lie between zero to one for 2003. Lower scores imply a less legal formality. Time-invariant index of complexity in collecting a commercial debt valued at $50 \%$ of annual GDP per capita, rescaled to lie between zero and one for 2003. Lower scores imply a less complexity.

Time-invariant composite governance index. It is calculated as the average of six variables: voice and accountability, political stability and absence of violence, government effectiveness, regulatory quality, rule of law, and control of corruption in 1996. It ranges from -2 to 2 . Higher values imply better governance.

Time varying variable that measures the extent of institutionalized constraints on the decision making powers of chief executives. This variable is calculated as the average for the periods 1960-1965, 1965-1970, 1970-1980, 1980-1985, 1985-1990, 1990-1995, 1995-2000, 2000-2005 and 2005-2009. This variable ranges from zero to seven where higher values equal a greater extent of institutionalized constraints on the power of chief executives.

\section{Other}

Time dummy variables

Dummy variables for 1960-1965, 1965-1970, 1970-1980, 1980-1985, 1985-1990, 1990-1995, 1995-2000, 2000-2005 and 2005-2009

Colonial (Spain or Portugal)

English legal origin
Binary variable where one indicates that country was colonized by Spain or Portugal.

Binary variable where one indicates that country was colonized by The United Kingdom, and English legal code was transferred. 
French legal origin

Latitude

Mineral stocks

System
Binary variable where one indicates that country was colonized by France, Spain, Belgium, Portugal or Germany and French legal code was transferred.

The absolute value of the latitude of the capital of the country, scaled to take values between zero and one.

Time-invariant variable that takes the value of the logarithm of fuel and 35 non fossil fuel stocks estimated for 1970 at market prices, in US dollars per capita.

Time-invariant variable that takes the value of 0 if the country has a presidential system, 1 if it has an assembly-elected president and 2 if it has a parliamentary system (mean value between 1975 and 2010).

Table A.2 Data sources

\begin{tabular}{|c|c|}
\hline Designation & Source(s) \\
\hline \multicolumn{2}{|l|}{ Neoclassical } \\
\hline Growth rates of per capita GDP & Penn World Tables 7.1 \\
\hline Initial income & Idem \\
\hline Population growth rates & Idem \\
\hline Investment in physical capital & Idem \\
\hline Schooling & Barro and Lee (2014) \\
\hline \multicolumn{2}{|l|}{ Demography } \\
\hline Life Expectancy & World Bank \\
\hline Fertility rate & Idem \\
\hline \multicolumn{2}{|l|}{ Macroeconomic policy } \\
\hline Openness & Penn World Tables 7.1 \\
\hline Government consumption & Idem \\
\hline Inflation & World Bank \\
\hline \multicolumn{2}{|l|}{ Regional heterogeneity } \\
\hline Latin America and Caribbean & World Bank country classification \\
\hline Sub-Saharan Africa & Idem \\
\hline East Asia and the Pacific & Idem \\
\hline South-East Asia & Idem \\
\hline \multicolumn{2}{|l|}{ Religion } \\
\hline Buddhism & World Christian Encyclopedia (2001) \\
\hline Catholicism & Idem \\
\hline Eastern Religion & Idem \\
\hline Hinduism & Idem \\
\hline Judaism & Idem \\
\hline Islam & Idem \\
\hline Orthodox & Idem \\
\hline Protestant & Idem \\
\hline Other & Idem \\
\hline \multicolumn{2}{|l|}{ Natural capital } \\
\hline Natural capital in wealth & World Bank \\
\hline $\begin{array}{l}\text { Natural capital in wealth } \\
\text { (renewable) }\end{array}$ & Idem \\
\hline $\begin{array}{l}\text { Natural capital in wealth } \\
\text { (non-renewable) }\end{array}$ & Idem \\
\hline Natural capital per capita & Idem \\
\hline $\begin{array}{l}\text { Natural capital per capita } \\
\text { (renewable) }\end{array}$ & Idem \\
\hline $\begin{array}{l}\text { Natural capital per capita } \\
\text { (non-renewable) }\end{array}$ & Idem \\
\hline
\end{tabular}




\begin{tabular}{ll}
\hline $\begin{array}{l}\text { Geography } \\
\text { Coastline } \\
\text { Landlocked }\end{array}$ & UNEP (2015) \\
\hline Fractionalization & Central Intelligence Agency (2009) \\
\hline $\begin{array}{l}\text { Language } \\
\text { Ethnic group }\end{array}$ & Alesina et al. (2003) \\
\hline Institutions & Idem \\
\hline Liberal democracy & \\
Public sector corruption & The QOG Standard Dataset \\
Legal formalism: Check (1) & Idem \\
Legal formalism: Check (2) & Djankov et al. (2003) \\
Complex & Doing Business, World Bank \\
KKZ96 & Idem \\
Executive constraints & Kaufmann et al. (2005) \\
\hline Other & Polity IV Project, 1946-2013 \\
\hline Time dummy variables & \\
Colonial (Spain or Portugal) & Own construction \\
English legal origin & Barro and Lee (1994) \\
French legal origin & Easterly (2001) \\
Latitude & La Porta et al. (1999) and Djankov et al. (2003) \\
Mineral stocks & Djankov et al. (2003) \\
System & Norman (2009) and van der Ploeg and Poelhekke (2010) \\
\hline
\end{tabular}

\section{Appendix 2: Descriptive Statistics and Preliminary Results}

Table A.3 Summary statistics

\begin{tabular}{llcccccc}
\hline \hline Designation & Variable & Obs. & Mean & Median & Std. Dev. & Min. & Max. \\
\hline Neoclassical & & & & & & & \\
Growth rates of GDP per capita & growth_pc & 797 & 0.02 & 0.02 & 0.03 & -0.11 & 0.12 \\
Initial income & income_in & 791 & 8.55 & 8.61 & 1.26 & 5.65 & 11.37 \\
Population growth rates & $\begin{array}{l}\text { popu. } \\
\text { invest }\end{array}$ & 830 & -2.72 & -2.73 & 0.19 & -3.22 & -1.56 \\
Investment in physical capital & 791 & 3.04 & 3.11 & 0.52 & 0.26 & 4.20 \\
Schooling & scho. & 830 & 3.21 & 3.40 & 0.78 & -0.05 & 4.41 \\
\hline Demography & & & & & & & \\
Life Expectancy & life. & 827 & 0.02 & 0.01 & 0.08 & 0.01 & 2.54 \\
Fertility rate & fert. & 828 & 1.28 & 1.32 & 0.52 & 0.01 & 2.10 \\
\hline Macroeconomic policy & & & & & & & \\
Openess & open & 793 & 0.62 & 0.51 & 0.45 & 0.04 & 4.20 \\
Government consumption & gov. & 808 & 0.09 & 0.08 & 0.06 & 0.00 & 0.41 \\
Inflation & infl. & 671 & 0.23 & 0.06 & 1.36 & -0.01 & 24.14 \\
\hline Regional heterogeneity & & & & & & & \\
Latin America and Caribbean & lac & 830 & 0.24 & 0.00 & 0.42 & 0.00 & 1.00 \\
Sub-Saharan Africa & ssa & 830 & 0.18 & 0.00 & 0.38 & 0.00 & 1.00 \\
East Asia and the Pacific & eac & 830 & 0.15 & 0.00 & 0.36 & 0.00 & 1.00 \\
South-East Asia & sea & 830 & 0.06 & 0.00 & 0.23 & 0.00 & 1.00 \\
\hline Religion & & & & & & & \\
Buddhism & buddhist & 830 & 0.03 & 0.00 & 0.14 & 0.00 & 0.92 \\
Catholicism & catholic & 830 & 0.36 & 0.17 & 0.37 & 0.00 & 0.99 \\
Eastern Religion & eastern & 830 & 0.02 & 0.00 & 0.07 & 0.00 & 0.46 \\
Hinduism & hindu & 830 & 0.03 & 0.00 & 0.11 & 0.00 & 0.77 \\
Judaism & jew & 830 & 0.01 & 0.00 & 0.09 & 0.00 & 0.85 \\
Islam & muslim & 830 & 0.20 & 0.01 & 0.34 & 0.00 & 0.99 \\
Orthodox religion & orthodox & 830 & 0.02 & 0.00 & 0.10 & 0.00 & 0.94 \\
Protestantism & protestant & 830 & 0.15 & 0.04 & 0.24 & 0.00 & 1.09 \\
& & & & & & & 29
\end{tabular}




\begin{tabular}{|c|c|c|c|c|c|c|c|}
\hline Other & other & 830 & 0.04 & 0.00 & 0.13 & -0.42 & 0.58 \\
\hline \multicolumn{8}{|l|}{ Natural capital } \\
\hline Natural capital in wealth & natural_w & 830 & 0.27 & 0.17 & 0.32 & 0.00 & 2.22 \\
\hline $\begin{array}{l}\text { Natutal capital in wealth } \\
\text { (renewable) }\end{array}$ & natural_w_r & 830 & 0.20 & 0.09 & 0.23 & 0.00 & 1.26 \\
\hline $\begin{array}{l}\text { Natural capital in wealth } \\
\text { (non-renewable) }\end{array}$ & $n a t u r a l \_w \_n r$ & 830 & 0.06 & 0.01 & 0.19 & 0.00 & 2.21 \\
\hline Natural capital per capita & natural_pc & 830 & 0.11 & 0.05 & 0.17 & 0.00 & 1.00 \\
\hline $\begin{array}{l}\text { Natural capital per capita } \\
\text { (renewable) }\end{array}$ & natural_pc_r & 830 & 0.14 & 0.09 & 0.15 & 0.00 & 1.00 \\
\hline $\begin{array}{l}\text { Natural capital per capita } \\
\text { (non-renewable) }\end{array}$ & $n a t u r a l \_p c \_n r$ & 830 & 0.05 & 0.00 & 0.16 & 0.00 & 1.00 \\
\hline \multicolumn{8}{|l|}{ Geography } \\
\hline Coastline & coastaline & 830 & 0.05 & 0.01 & 0.13 & 0.00 & 1.00 \\
\hline Landlocked & landlock & 830 & 0.09 & 0.00 & 0.28 & 0.00 & 1.00 \\
\hline \multicolumn{8}{|l|}{ Fractionalization } \\
\hline$\overline{\text { Language }}$ & language & 810 & 0.34 & 0.33 & 0.29 & 0.00 & 0.92 \\
\hline Ethnic tensions & ethnic & 820 & 0.42 & 0.42 & 0.26 & 0.00 & 0.93 \\
\hline \multicolumn{8}{|l|}{ Institutions } \\
\hline Liberal democracy & democracy & 770 & 0.43 & 0.38 & 0.29 & 0.02 & 0.95 \\
\hline Public sector corruption & corruption & 770 & 0.41 & 0.40 & 0.29 & 0.00 & 0.97 \\
\hline Legal formalism: Check (1) & $\operatorname{check}(1)$ & 660 & 3.54 & 3.39 & 1.10 & 1.42 & 6.01 \\
\hline Legal formalism: Check (2) & $\operatorname{check}(2)$ & 580 & 0.42 & 0.38 & 0.18 & 0.09 & 0.83 \\
\hline Complex & complex & 710 & 0.56 & 0.53 & 0.15 & 0.29 & 0.86 \\
\hline KKZ96 & $k k z 96$ & 830 & 0.28 & 0.08 & 0.90 & -1.69 & 1.92 \\
\hline Executive constraints & exe_constr & 770 & 4.73 & 5.00 & 2.22 & 0.80 & 7.00 \\
\hline \multicolumn{8}{|l|}{ Other } \\
\hline$\overline{\text { Time dummy variables }}$ & year_dummy & & & & & & \\
\hline Colonial (Spain or Portugal) & colonial & 790 & 0.19 & 0.00 & 0.39 & 0.00 & 1.00 \\
\hline English legal origin & english & 830 & 0.44 & 0.00 & 0.49 & 0.00 & 1.00 \\
\hline French legal origin & french & 790 & 0.08 & 0.00 & 0.28 & 0.00 & 1.00 \\
\hline Latitude & latitude & 830 & 0.27 & 0.22 & 0.19 & 0.01 & 0.71 \\
\hline Mineral stocks & minerals & 780 & -6.31 & -6.25 & 2.96 & -14.51 & 0.26 \\
\hline System & system & 820 & 0.89 & 0.55 & 0.89 & 0.00 & 2.00 \\
\hline
\end{tabular}

Table A.4 Correlations between proximate and fundamental theories' proxy vatiables ${ }^{+}$

\begin{tabular}{|c|c|c|c|c|c|c|c|c|c|c|c|}
\hline \multirow{2}{*}{ Fundamental } & \multicolumn{11}{|c|}{ Proximate } \\
\hline & popu. & invest & scho. & life. & fert. & open & gov. & infl. & $l a c$ & ssa & sea \\
\hline$\overline{\text { catholic }}$ & -0.16 & -0.07 & -0.00 & 0.05 & -0.07 & -0.09 & -0.23 & 0.13 & 0.54 & -0.22 & -0.22 \\
\hline hindu & 0.06 & 0.00 & -0.06 & -0.00 & 0.11 & -0.09 & 0.14 & -0.02 & -0.10 & -0.06 & 0.70 \\
\hline muslim & 0.44 & -0.11 & -0.24 & -0.01 & 0.35 & 0.21 & 0.03 & -0.03 & -0.23 & 77 & 0.17 \\
\hline other & 0.41 & -0.14 & -0.28 & -0.01 & 0.42 & 0.0 & 0.12 & -0.01 & -0.10 & 3 & -0.00 \\
\hline \multicolumn{12}{|c|}{ Natural capital } \\
\hline natural_w & $\mathbf{0 . 5 3}$ & -0.18 & -0.34 & -0.02 & 0.59 & -0.03 & 0.17 & 0.06 & 0.13 & 8 & 0.19 \\
\hline natural_w_1 & 0.27 & -0.23 & -0.26 & -0.01 & 0.50 & 0.01 & & 0.03 & 0.06 & & 0.09 \\
\hline \multicolumn{12}{|c|}{ Fractionalization } \\
\hline language & 0.43 & -0.15 & -0.20 & -0.02 & 0.41 & 0.11 & & -0.03 & -0.32 & 0.57 & 0.27 \\
\hline ethnic & 0.60 & -0.23 & -0.30 & -0.04 & 0.61 & 0.13 & 0.06 & 0.11 & 0.26 & $\mathbf{0 . 5 0}$ & 0.09 \\
\hline democracy & -0.60 & 0.08 & 0.50 & 0.04 & -0.72 & -0.11 & -0.08 & -0.03 & -0.22 & -0.28 & -0.08 \\
\hline
\end{tabular}




\begin{tabular}{lccccccccccc} 
corruption & $\mathbf{0 . 5 5}$ & -0.20 & -0.42 & -0.02 & $\mathbf{0 . 6 5}$ & 0.12 & 0.08 & 0.08 & 0.28 & 0.32 & 0.02 \\
check $(1)$ & 0.11 & -0.09 & -0.22 & -0.08 & 0.21 & 0.07 & -0.01 & 0.13 & $\mathbf{0 . 5 0}$ & -0.16 & 0.08 \\
check $(2)$ & 0.11 & -0.09 & -0.23 & -0.08 & 0.22 & 0.08 & -0.02 & 0.13 & $\mathbf{0 . 5 0}$ & -0.17 & 0.02 \\
kkz 96 & $\mathbf{- 0 . 6 3}$ & 0.24 & $\mathbf{0 . 4 5}$ & 0.03 & $\mathbf{- 0 . 7 3}$ & -0.06 & -0.14 & -0.11 & -0.36 & -0.38 & -0.27 \\
exe_constr & $\mathbf{- 0 . 4 8}$ & 0.04 & $\mathbf{0 . 4 7}$ & 0.00 & $\mathbf{- 0 . 5 7}$ & -0.09 & -0.09 & -0.00 & -0.11 & -0.24 & 0.04 \\
\hline
\end{tabular}

${ }^{+}$The figures reported in this table are conditioned by the value of the correlation coefficients being greater than equal to 0.40 . The complete correlation matrix is available from the authors upon request.

Table A.5 Neoclassical variables for CART and median cut-off points

\begin{tabular}{lcccc}
\hline \hline Cut-off point & income_ini & popu. & invest & scho. \\
\hline CART cut-off point & & & & \\
invest $\geq 2.75$ & 8.82 & -2.73 & 3.22 & 3.32 \\
invest $<2.75$ & 7.46 & -2.64 & 2.25 & 2.70 \\
\hline Median cut-off point & & & & \\
invest $\geq 3.10$ & 8.86 & -2.72 & 3.38 & 3.29 \\
invest $<3.10$ & 8.23 & -2.71 & 2.66 & 3.11 \\
\hline
\end{tabular}

Table A.6 Estimation results for the existence of multiple economic growth regimes ${ }^{+}$

\begin{tabular}{|c|c|c|c|c|}
\hline Sample & OLS & FE & DIF-GMM & SYS-GMM \\
\hline \multicolumn{5}{|l|}{ Full sample } \\
\hline $\bar{\lambda}$ & -0.002 & -0.021 & -0.071 & -0.012 \\
\hline Observations & 791 & 791 & 599 & 678 \\
\hline$F$ & $13.45 * * *$ & $4.14 * * *$ & & \\
\hline Wald & & & 63.89 & $4537 * * *$ \\
\hline Hansen & & & & 32.99 \\
\hline$m_{1}$ & & & $-3.54 * * *$ & $-3.97 * * *$ \\
\hline$m_{2}$ & & & -0.99 & $-1.69 *$ \\
\hline \multicolumn{5}{|c|}{ Sub-sample: invest $\geq 3.10$} \\
\hline$\lambda$ & -0.006 & -0.021 & -0.098 & -0.014 \\
\hline Observations & 401 & 401 & 304 & 346 \\
\hline$F$ & $10.36 * * *$ & $4.60 * * *$ & & \\
\hline Wald & & & 48.10 & $2234 * * *$ \\
\hline Hansen & & & & 51.45 \\
\hline$m_{1}$ & & & $-2.85 * * *$ & $-3.97 * * *$ \\
\hline$m_{2}$ & & & -0.14 & -0.49 \\
\hline \multicolumn{5}{|c|}{ Sub-sample: invest $<3.10$} \\
\hline$\lambda$ & -0.000 & -0.015 & -0.070 & -0.005 \\
\hline Observations & 390 & 390 & 295 & 342 \\
\hline$F$ & $6.16^{* * *}$ & $2.72 * * *$ & & \\
\hline Wald & & & 65.64 & $8548 * * *$ \\
\hline Hansen & & & & 29.85 \\
\hline$m_{1}$ & & & $-2.57 * *$ & $-3.48^{* * *}$ \\
\hline$m_{2}$ & & & -1.08 & -1.27 \\
\hline Chow & $2.56 * *$ & $17.34 * * *$ & - & - \\
\hline
\end{tabular}

${ }^{+}$Significance at the $10 \%, 5 \%$, and $1 \%$ significance levels are indicated by, ${ }^{*},{ }^{*}$, and ${ }^{* * *}$ respectivement.

Table A.7 Summary statistics according to the median cut-off point in investment in physical capital

\begin{tabular}{llcccc}
\hline \hline & & invest & 2.10 & \multicolumn{2}{c}{ invest $<3.10$} \\
Designation & Variable & Obs. & Mean & Obs. & Mean \\
\hline Neoclassical & & & & & \\
Growth rates of pc GDP & growth_pc & 407 & 0.02 & 390 & 0.01 \\
Initial income & income_in & 401 & 8.86 & 390 & 8.23 \\
Population growth rates & popu. & 440 & -2.72 & 390 & -2.71
\end{tabular}




\begin{tabular}{|c|c|c|c|c|c|}
\hline $\begin{array}{l}\text { Investment in physical capital } \\
\text { Schooling }\end{array}$ & $\begin{array}{l}\text { invest } \\
\text { scho. }\end{array}$ & $\begin{array}{l}401 \\
440 \\
\end{array}$ & $\begin{array}{l}3.38 \\
3.29 \\
\end{array}$ & $\begin{array}{l}390 \\
390 \\
\end{array}$ & $\begin{array}{l}2.66 \\
3.11 \\
\end{array}$ \\
\hline \multicolumn{6}{|l|}{ Demography } \\
\hline Life Expectancy & life. & 437 & 0.01 & 390 & 0.02 \\
\hline Fertility rate & fert. & 438 & 1.20 & 390 & 1.36 \\
\hline \multicolumn{6}{|l|}{ Macroeconomic policy } \\
\hline Openness & open & 404 & 0.73 & 389 & 0.51 \\
\hline Government consumption & gov. & 418 & 0.09 & 390 & 0.09 \\
\hline Inflation & infl. & 353 & 0.08 & 318 & 0.38 \\
\hline \multicolumn{6}{|l|}{ Regional heterogeneity } \\
\hline Latin America and Caribbean & lac & 440 & 0.22 & 390 & 0.26 \\
\hline Sub-Saharan Africa & ssa & 440 & 0.11 & 390 & 0.25 \\
\hline South-East Asia & sea & 440 & 0.05 & 390 & 0.07 \\
\hline \multicolumn{6}{|l|}{ Religion } \\
\hline Buddhism & buddhism & 440 & 0.05 & 390 & 0.01 \\
\hline Catholicism & catholic & 440 & 0.35 & 390 & 0.36 \\
\hline Eastern Religion & eastern & 440 & 0.03 & 390 & 0.01 \\
\hline Hinduism & hindu & 440 & 0.03 & 390 & 0.04 \\
\hline Judaism & jew & 440 & 0.01 & 390 & 0.01 \\
\hline Islam & muslim & 440 & 0.20 & 390 & 0.20 \\
\hline Orthodox religion & orthodox & 440 & 0.02 & 390 & 0.01 \\
\hline Protestant & protestant & 440 & 0.14 & 390 & 0.15 \\
\hline Other & other & 440 & 0.01 & 390 & 0.06 \\
\hline \multicolumn{6}{|l|}{ Natural capital } \\
\hline Natural capital in wealth & natural_w & 440 & 0.14 & 390 & 0.28 \\
\hline $\begin{array}{l}\text { Natural capital in wealth } \\
\text { (renewable) }\end{array}$ & natural_w_r & 440 & 0.16 & 390 & 0.23 \\
\hline $\begin{array}{l}\text { Natural capital in wealth } \\
\text { (non-renewable) }\end{array}$ & natural_w_nr & 440 & 0.08 & 390 & 0.04 \\
\hline Natural capital per capita & natural_pc & 440 & 0.12 & 390 & 0.08 \\
\hline $\begin{array}{l}\text { Natural capital per capita } \\
\text { (renewable) }\end{array}$ & natural_pc_r & 440 & 0.15 & 390 & 0.13 \\
\hline $\begin{array}{l}\text { Natural capital per capita } \\
\text { (non-renewable) }\end{array}$ & natural_pc_nr & 440 & 0.06 & 390 & 0.03 \\
\hline \multicolumn{6}{|l|}{ Geography } \\
\hline Coastline & coastline & 440 & 0.04 & 390 & 0.11 \\
\hline \multicolumn{6}{|l|}{ Fractionalization } \\
\hline$\overline{\text { Language }}$ & language & 429 & 0.31 & 381 & 0.38 \\
\hline Ethnic tensions & ethnic & 430 & 0.37 & 390 & 0.46 \\
\hline \multicolumn{6}{|l|}{ Institutions } \\
\hline$\overline{\text { Liberal democracy }}$ & democracy & 376 & 0.41 & 364 & 0.46 \\
\hline Public sector corruption & corruption & 376 & 0.43 & 364 & 0.42 \\
\hline Legal formalism: Check (1) & $\operatorname{check}(1)$ & 301 & 0.42 & 279 & 0.42 \\
\hline Legal formalism: Check (2) & $\operatorname{check}(2)$ & 348 & 3.50 & 312 & 3.57 \\
\hline Complex & complex & 357 & 0.56 & 353 & 0.55 \\
\hline KKZ96 & $k k z 96$ & 440 & 0.44 & 390 & 0.11 \\
\hline Executive constraints & exe_constr & 401 & 4.73 & 369 & 4.72 \\
\hline \multicolumn{6}{|l|}{ Other } \\
\hline Time dummy variables & year_dummy & & & & \\
\hline Colonial (Spain or Portugal) & colonial & 412 & 0.15 & 378 & 0.22 \\
\hline English legal origin & english & 440 & 0.42 & 390 & 0.46 \\
\hline French legal origin & french & 412 & 0.08 & 378 & 0.09 \\
\hline Latitude & latitude & 440 & 0.29 & 390 & 0.26 \\
\hline Mineral stocks & minerals & 404 & -6.09 & 376 & -6.54 \\
\hline System & system & 431 & 1.02 & 389 & 0.75 \\
\hline
\end{tabular}


Table A.8 Correlations between proximate and fundamental theories' proxy variables for countries above the median cut-off point in investment in physical capital ${ }^{+}$

\begin{tabular}{|c|c|c|c|c|c|c|c|c|c|c|c|}
\hline Fundamental & \multicolumn{11}{|c|}{ Proximate } \\
\hline Religion & рори. & invest & scho. & life. & fert. & open & gov. & infl. & lac & ssa & sea \\
\hline buddhi & -0.14 & 0.22 & -0.04 & 0.00 & -0.02 & 0.04 & -0.04 & -0.10 & -0.16 & -0.09 & 0.41 \\
\hline hindu & & -0 . & 0.08 & 0.09 & 0.09 & & & -0.02 & -0.08 & & 75 \\
\hline musl & 0.5 & 0.34 & -0.05 & 0.14 & 0.31 & & & -0.0 & -0.18 & & \\
\hline other & & & -0.20 & & 0.36 & & & & & & \\
\hline \multicolumn{12}{|c|}{ Natural capital } \\
\hline natural_w & 0.42 & 0.25 & -0.38 & 0.62 & 0.52 & 0.05 & & 0.19 & 0.26 & & 0.08 \\
\hline natural_w_l & 0.10 & 0.0 & -0.17 & 0.45 & 0.44 & 0.0 & & .13 & 0.20 & & 0.04 \\
\hline \multicolumn{12}{|c|}{ Fractionalization } \\
\hline language & 0.34 & -0.03 & -0.15 & 0.43 & 0.35 & 0.21 & 0.01 & -0.02 & -0.22 & 0.44 & 0.18 \\
\hline ethnic & & & -0.32 & 0.55 & 0.57 & 0.35 & & 0.21 & 0.32 & & 0.05 \\
\hline \multicolumn{12}{|l|}{ Institutions } \\
\hline$\overline{\text { democracy }}$ & -0.59 & -0.34 & 0.43 & -0.60 & -0.69 & -0.20 & -0.15 & -0.23 & -0.25 & -0.26 & -0.04 \\
\hline corruption & 0.42 & 0.20 & -0.37 & 0.50 & 0.52 & 0.16 & 0.11 & 0.22 & 0.29 & 0.20 & -0.00 \\
\hline $\operatorname{check}(2)$ & 0.08 & -0.03 & -0.22 & 0.08 & 0.15 & -0.05 & 0.01 & 0.13 & 0.40 & -0.17 & 0.07 \\
\hline$k k z 96$ & -0.57 & -0.21 & 0.35 & -0.64 & -0.66 & -0.16 & -0.27 & -0.31 & -0.43 & -0.32 & -0.26 \\
\hline exe_constr & -0.50 & -0.38 & 0.46 & -0.51 & -0.58 & -0.13 & -0.11 & -0.22 & -0.16 & -0.16 & 0.07 \\
\hline
\end{tabular}

${ }^{+}$The figures reported in this table are conditioned by the value of the correlation coefficients being greater than equal to 0.40 . The complete correlation matrix is available from the authors upon request.

Table A.9 Correlations between proximate and fundamental theories' proxy variables for countries below the median cut-off point in investment in physical capital ${ }^{+}$

\begin{tabular}{lcccccccccccc}
\hline \hline Fundamental & & \multicolumn{10}{c}{ Proximate } \\
\hline \multicolumn{1}{l}{} & popu. & invest & scho. & life. & fert. & open & gov. & infl. & lac & ssa & sea \\
Religion & & & & & & & & & & & \\
catholic & -0.18 & 0.05 & 0.07 & 0.07 & -0.11 & -0.01 & -0.24 & 0.19 & $\mathbf{0 . 7 1}$ & -0.29 & -0.28 \\
hindu & 0.04 & 0.13 & -0.12 & -0.01 & 0.11 & -0.20 & 0.16 & -0.03 & -0.12 & -0.08 & $\mathbf{0 . 6 9}$ \\
other & $\mathbf{0 . 4 8}$ & -0.26 & -0.32 & -0.03 & $\mathbf{0 . 4 6}$ & -0.02 & 0.09 & -0.03 & -0.16 & $\mathbf{0 . 7 4}$ & -0.01 \\
protestant & $\mathbf{- 0 . 4 1}$ & 0.20 & 0.37 & -0.04 & $\mathbf{- 0 . 4 5}$ & 0.04 & 0.04 & -0.09 & -0.29 & -0.05 & -0.18 \\
\hline \multicolumn{2}{l}{ Natural capital } & & & & & & & & & & & \\
natural_w & $\mathbf{0 . 6 0}$ & -0.30 & -0.29 & -0.05 & $\mathbf{0 . 6 2}$ & -0.05 & 0.18 & 0.05 & 0.00 & $\mathbf{0 . 5 3}$ & 0.25 \\
natural_w_1 & $\mathbf{0 . 4 1}$ & -0.30 & -0.29 & -0.04 & $\mathbf{0 . 5 3}$ & 0.09 & 0.37 & 0.01 & -0.08 & $\mathbf{0 . 4 9}$ & 0.11 \\
\hline Fractionalization & & & & & & & & & & \\
language & $\mathbf{0 . 4 9}$ & -0.13 & -0.21 & -0.04 & $\mathbf{0 . 4 4}$ & 0.06 & 0.17 & -0.06 & $-\mathbf{0 . 4 2}$ & $\mathbf{0 . 6 4}$ & 0.33 \\
ethnic & $\mathbf{0 . 6 1}$ & -0.31 & -0.26 & -0.08 & $\mathbf{0 . 6 1}$ & -0.02 & 0.04 & 0.11 & 0.18 & $\mathbf{0 . 5 6}$ & 0.09 \\
\hline Institutions & & & & & & & & & & & \\
democracy & $\mathbf{- 0 . 6 2}$ & 0.39 & $\mathbf{0 . 5 6}$ & 0.07 & $\mathbf{- 0 . 7 7}$ & -0.03 & 0.00 & -0.02 & -0.19 & -0.29 & -0.11 \\
corruption & $\mathbf{0 . 6 5}$ & $\mathbf{- 0 . 4 1}$ & $\mathbf{- 0 . 4 5}$ & -0.05 & $\mathbf{0 . 7 0}$ & 0.16 & 0.04 & 0.07 & 0.25 & 0.38 & 0.03 \\
check(1) & 0.13 & -0.21 & -0.23 & -0.01 & 0.26 & 0.26 & -0.06 & 0.17 & $\mathbf{0 . 5 8}$ & -0.17 & 0.01 \\
check(2) & 0.13 & -0.19 & -0.21 & -0.01 & 0.26 & 0.24 & -0.04 & 0.16 & $\mathbf{0 . 5 8}$ & -0.16 & 0.08 \\
k $k z 96$ & $\mathbf{- 0 . 6 7}$ & $\mathbf{0 . 4 0}$ & $\mathbf{0 . 5 1}$ & 0.06 & $\mathbf{- 0 . 7 7}$ & -0.03 & -0.01 & -0.11 & -0.29 & $\mathbf{- 0 . 4 0}$ & 0.27 \\
exe_constr & $\mathbf{- 0 . 4 7}$ & 0.36 & $\mathbf{0 . 4 8}$ & 0.01 & $\mathbf{- 0 . 5 8}$ & -0.07 & -0.08 & 0.02 & -0.06 & -0.31 & 0.03 \\
\hline
\end{tabular}

${ }^{+}$The figures reported in this table are conditioned by the value of the correlation coefficients being greater than equal to 0.40 . The complete correlation matrix is available from the authors upon request.

\section{Appendix 3: BMA Estimation Results}

Table A.10 BMA estimation results for average growth rates of per capita GDP: Full sample ${ }^{+}$

\begin{tabular}{lcccccc}
\hline \hline & \multicolumn{2}{c}{ Proximate and fundamental theories } & \multicolumn{2}{c}{ Fundamental theories } \\
\hline Explanatory variable & Posterior & Posterior & Posterior & Posterior & Posterior & Posterior \\
\hline
\end{tabular}




\begin{tabular}{|c|c|c|c|c|c|c|}
\hline & $\begin{array}{l}\text { inclusion } \\
\text { probability } \\
(\#)\end{array}$ & mean & $\begin{array}{l}\text { standard } \\
\text { deviation }\end{array}$ & $\begin{array}{l}\text { inclusion } \\
\text { probability } \\
(\#)\end{array}$ & mean & $\begin{array}{c}\text { standard } \\
\text { deviation }\end{array}$ \\
\hline \multicolumn{7}{|l|}{ Neoclassical } \\
\hline income_in & & $-0.051^{*}$ & 0.008 & & $-0.014 *$ & 0.006 \\
\hline рори. & & -0.016 & 0.050 & & & \\
\hline invest & & 0.018 & 0.012 & & & \\
\hline scho. & & -0.012 & 0.010 & & & \\
\hline Demography & 1.000 & & & & & \\
\hline life. & & -0.006 & 0.024 & & & \\
\hline fert. & & $-0.159^{*}$ & 0.025 & & & \\
\hline Macroeconomic policy & 0.028 & & & & & \\
\hline open & & -0.000 & 0.001 & & & \\
\hline gov. & & -0.000 & 0.013 & & & \\
\hline Infl. & & -0.001 & 0.000 & & & \\
\hline Regional heterogeneity & 0.085 & & & & & \\
\hline lac & & 0.000 & 0.001 & & & \\
\hline ssa & & -0.002 & 0.010 & & & \\
\hline sea & & 0.000 & 0.002 & & & \\
\hline Religion & 0.981 & & & 1.000 & & \\
\hline$\overline{\text { eastern }}$ & & $0.288 *$ & 0.076 & & $0.433 *$ & 0.062 \\
\hline hindu & & 0.001 & 0.012 & & 0.017 & 0.039 \\
\hline muslim & & 0.000 & 0.004 & & -0.001 & 0.007 \\
\hline protestant & & -0.003 & 0.012 & & -0.003 & 0.012 \\
\hline other & & 0.001 & 0.013 & & 0.000 & 0.011 \\
\hline Natural capital & 0.250 & & & 0.227 & & \\
\hline$\overline{n a t u r a l \_w}$ & & -0.006 & 0.018 & & -0.012 & 0.026 \\
\hline natural_pc & & 0.000 & 0.000 & & 0.000 & 0.000 \\
\hline Geography & 0.056 & & & 0.035 & & \\
\hline coastline & & -0.000 & 0.004 & & 0.000 & 0.005 \\
\hline landlocked & & -0.001 & 0.006 & & -0.000 & 0.003 \\
\hline Fractionalization & 0.056 & & & 0.964 & & \\
\hline$\overline{\text { language }}$ & & -0.001 & 0.006 & & -0.002 & 0.010 \\
\hline ethnic & & -0.000 & 0.004 & & $-0.089^{*}$ & 0.031 \\
\hline Institutions & 1.000 & & & 1.000 & & \\
\hline$\overline{k k z 96}$ & & -0.000 & 0.002 & & 0.000 & 0.003 \\
\hline exe_constr & & $-0.006 *$ & 0.003 & & 0.000 & 0.003 \\
\hline Observations & & 640 & & & 640 & \\
\hline
\end{tabular}

Table A.11 BMA estimation results for average growth rates of per capita GDP: invest $\geq 3.10^{+}$

\begin{tabular}{|c|c|c|c|c|c|c|}
\hline \multirow[b]{2}{*}{ Explanatory variable } & \multicolumn{3}{|c|}{ Proximate and fundamental theories } & \multicolumn{3}{|c|}{ Fundamental theories } \\
\hline & $\begin{array}{l}\text { Posterior } \\
\text { inclusion } \\
\text { probability } \\
(\#)\end{array}$ & $\begin{array}{l}\text { Posterior } \\
\text { mean }\end{array}$ & $\begin{array}{l}\text { Posterior } \\
\text { standard } \\
\text { deviation }\end{array}$ & $\begin{array}{c}\text { Posterior } \\
\text { inclusion } \\
\text { probability } \\
(\#)\end{array}$ & $\begin{array}{l}\text { Posterior } \\
\text { mean }\end{array}$ & $\begin{array}{l}\text { Posterior } \\
\text { standard } \\
\text { deviation }\end{array}$ \\
\hline \multicolumn{7}{|l|}{ Neoclassical } \\
\hline$\overline{\text { income_in }}$ & & $-0.073 *$ & 0.010 & & $-0.032 *$ & 0.009 \\
\hline pop. & & 0.044 & 0.063 & & & \\
\hline invest & & -0.053 & 0.033 & & & \\
\hline scho. & & -0.014 & 0.015 & & & \\
\hline
\end{tabular}

Demography

1.000 


\begin{tabular}{|c|c|c|c|c|c|c|}
\hline $\begin{array}{l}\text { life. } \\
\text { fert. }\end{array}$ & & $\begin{array}{c}0.116 \\
-0.199^{*} \\
\end{array}$ & $\begin{array}{l}1.485 \\
0.031 \\
\end{array}$ & & & \\
\hline Macroeconomic policy & 0.973 & & & & & \\
\hline open & & -0.001 & 0.006 & & & \\
\hline gov. & & -0.007 & 0.052 & & & \\
\hline infl. & & $-0.303^{*}$ & 0.092 & & & \\
\hline Regional heterogeneity & 0.002 & & & & & \\
\hline lac & & 0.000 & 0.002 & & & \\
\hline & & -0.000 & 0.003 & & & \\
\hline sea & & -0.000 & 0.004 & & & \\
\hline Religion & 0.980 & & & 1.000 & & \\
\hline$\overline{\text { eastern }}$ & & $0.302^{*}$ & 0.083 & & $0.433^{*}$ & 0.069 \\
\hline hindu & & 0.037 & 0.067 & & 0.129 & 0.102 \\
\hline muslim & & -0.000 & 0.007 & & -0.008 & 0.021 \\
\hline protestant & & -0.000 & 0.008 & & -0.000 & 0.007 \\
\hline other & & 0.003 & 0.025 & & -0.000 & 0.021 \\
\hline Natural capital & 0.170 & & & 0.084 & & \\
\hline natural_w & & -0.002 & 0.014 & & -0.003 & 0.016 \\
\hline natural_pc & & 0.000 & 0.000 & & 0.000 & 0.000 \\
\hline $\begin{array}{l}\text { Geography } \\
\end{array}$ & 0.078 & & & 0.037 & & \\
\hline coastline & & -0.000 & 0.010 & & 0.000 & 0.003 \\
\hline landlocked & & -0.002 & 0.010 & & 0.000 & 0.003 \\
\hline Fractionalization & 0.092 & & & 0.992 & & \\
\hline$\overline{\text { language }}$ & & -0.002 & 0.012 & & -0.000 & 0.009 \\
\hline ethnic & & -0.001 & 0.008 & & $-0.138^{*}$ & 0.036 \\
\hline Institutions & 1.000 & & & 0.999 & & \\
\hline$k k z 96$ & & -0.000 & 0.004 & & 0.000 & 0.004 \\
\hline exe_constr & & -0.006 & 0.004 & & 0.001 & 0.004 \\
\hline Observations & & 338 & & & 338 & \\
\hline
\end{tabular}

Table A.12 BMA estimation results for average growth rates of per capita GDP: invest $<3.10^{+}$

\begin{tabular}{|c|c|c|c|c|c|c|}
\hline \multirow[b]{2}{*}{ Explanatory variable } & \multicolumn{3}{|c|}{ Proximate and fundamental theories } & \multicolumn{3}{|c|}{ Fundamental theories } \\
\hline & $\begin{array}{l}\text { Posterior } \\
\text { inclusion } \\
\text { probability } \\
\text { (\#) }\end{array}$ & $\begin{array}{c}\text { Posterior } \\
\text { mean }\end{array}$ & $\begin{array}{l}\text { Posterior } \\
\text { standard } \\
\text { deviation }\end{array}$ & $\begin{array}{l}\text { Posterior } \\
\text { inclusion } \\
\text { probability } \\
(\#)\end{array}$ & $\begin{array}{c}\text { Posterior } \\
\text { mean }\end{array}$ & $\begin{array}{l}\text { Posterior } \\
\text { standard } \\
\text { deviation }\end{array}$ \\
\hline \multicolumn{7}{|l|}{ Neoclassical } \\
\hline income_in & & 0.000 & 0.012 & & 0.009 & 0.008 \\
\hline рори. & & $-0.151^{*}$ & 0.075 & & & \\
\hline invest & & 0.037 & 0.022 & & & \\
\hline scho. & & -0.019 & 0.014 & & & \\
\hline Demography & 0.161 & & & & & \\
\hline life. & & -0.001 & 0.011 & & & \\
\hline fert. & & -0.011 & 0.032 & & & \\
\hline Macroeconomic policy & 0.041 & & & & & \\
\hline open & & -0.000 & 0.002 & & & \\
\hline gov_consu & & -0.000 & 0.016 & & & \\
\hline infl. & & -0.000 & 0.001 & & & \\
\hline Regional heterogeneity & 0.384 & & & & & \\
\hline lac & & -0.000 & 0.003 & & & \\
\hline ssa & & -0.024 & 0.036 & & & \\
\hline
\end{tabular}




\begin{tabular}{|c|c|c|c|c|c|c|}
\hline sea & & 0.001 & 0.008 & & & \\
\hline Religion & 0.241 & & & 0.116 & & \\
\hline$\overline{\text { eastern }}$ & & 0.017 & 0.085 & & 0.026 & 0.111 \\
\hline hindu & & 0.000 & 0.007 & & 0.001 & 0.013 \\
\hline muslim & & 0.002 & 0.011 & & 0.000 & 0.003 \\
\hline protestant & & -0.010 & 0.030 & & -0.005 & 0.021 \\
\hline other & & 0.019 & 0.062 & & 0.000 & 0.006 \\
\hline Natural capital & 0.096 & & & 0.341 & & \\
\hline natural_w & & -0.003 & 0.014 & & -0.023 & 0.036 \\
\hline natural_pc & & 0.000 & 0.000 & & 0.000 & 0.000 \\
\hline Geography & 0.065 & & & 0.088 & & \\
\hline coastline & & 0.000 & 0.006 & & 0.000 & 0.006 \\
\hline landlocked & & -0.001 & 0.008 & & -0.002 & 0.001 \\
\hline Fractionalization & 0.052 & & & 0.083 & & \\
\hline$\overline{\text { language }}$ & & 0.000 & 0.007 & & -0.000 & 0.006 \\
\hline ethnic & & 0.000 & 0.006 & & -0.002 & 0.012 \\
\hline Institutions & 0.999 & & & 1.000 & & \\
\hline$\overline{k k z 96}$ & & -0.001 & 0.006 & & 0.000 & 0.003 \\
\hline exe_constr & & -0.007 & 0.004 & & -0.004 & 0.004 \\
\hline Observations & & 308 & & & 308 & \\
\hline
\end{tabular}

Table A.13 BMA estimation results for average growth rates of per capita GDP: Full sample (renewable natural capital) $^{+}$

\begin{tabular}{|c|c|c|c|c|c|c|}
\hline \multirow[b]{2}{*}{ Explanatory variable } & \multicolumn{3}{|c|}{ Proximate and fundamental theories } & \multicolumn{3}{|c|}{ Fundamental theories } \\
\hline & $\begin{array}{l}\text { Posterior } \\
\text { inclusion } \\
\text { probability } \\
(\#)\end{array}$ & $\begin{array}{c}\text { Posterior } \\
\text { mean }\end{array}$ & $\begin{array}{l}\text { Posterior } \\
\text { standard } \\
\text { deviation }\end{array}$ & $\begin{array}{c}\text { Posterior } \\
\text { inclusion } \\
\text { probability } \\
(\#)\end{array}$ & $\begin{array}{c}\text { Posterior } \\
\text { mean }\end{array}$ & $\begin{array}{l}\text { Posterior } \\
\text { standard } \\
\text { deviation }\end{array}$ \\
\hline \multicolumn{7}{|l|}{ Neoclassical } \\
\hline income_in & & $-0.051 *$ & 0.008 & & $-0.018^{*}$ & 0.008 \\
\hline рори. & & -0.017 & 0.049 & & & \\
\hline invest & & 0.017 & 0.012 & & & \\
\hline scho. & & -0.003 & 0.010 & & & \\
\hline Demography & 1.000 & & & & & \\
\hline life_exp & & -0.007 & 0.025 & & & \\
\hline fertility & & $-0.162 *$ & 0.025 & & & \\
\hline Macroeconomic policy & 0.024 & & & & & \\
\hline open & & -0.000 & 0.001 & & & \\
\hline gov. & & -0.000 & 0.010 & & & \\
\hline infl. & & -0.001 & 0.000 & & & \\
\hline Regional heterogeneity & 0.053 & & & & & \\
\hline lac & & 0.000 & 0.001 & & & \\
\hline ssa & & -0.001 & 0.006 & & & \\
\hline sea & & 0.000 & 0.002 & & & \\
\hline Religion & 0.943 & & & 1.000 & & \\
\hline$\overline{\text { eastern }}$ & & $0.258^{*}$ & 0.089 & & $0.416^{*}$ & 0.063 \\
\hline hindu & & 0.002 & 0.013 & & 0.025 & 0.047 \\
\hline muslim & & 0.000 & 0.005 & & -0.004 & 0.013 \\
\hline protestant & & -0.001 & 0.008 & & -0.002 & 0.010 \\
\hline other & & 0.002 & 0.015 & & 0.001 & 0.012 \\
\hline
\end{tabular}




\begin{tabular}{|c|c|c|c|c|c|c|}
\hline $\begin{array}{l}n a t u r a l \_w \_r \\
n a t u r a l \_p c \_r\end{array}$ & & $\begin{array}{c}-0.015 \\
0.000\end{array}$ & $\begin{array}{l}0.038 \\
0.000\end{array}$ & & $\begin{array}{c}-0.082 \\
0.000\end{array}$ & $\begin{array}{l}0.075 \\
0.000\end{array}$ \\
\hline Geography & 0.074 & & & 0.034 & & \\
\hline coastline & & -0.000 & 0.004 & & 0.000 & 0.005 \\
\hline landlocked & & -0.001 & 0.008 & & -0.000 & 0.003 \\
\hline Fractionalization & 0.043 & & & 0.984 & & \\
\hline language & & -0.000 & 0.004 & & -0.004 & 0.015 \\
\hline ethnic & & -0.000 & 0.003 & & $-0.084 *$ & 0.031 \\
\hline Institutions & 1.000 & & & 1.000 & & \\
\hline$\overline{k k z 96}$ & & -0.000 & 0.004 & & 0.000 & 0.002 \\
\hline exe_constr & & $-0.008^{*}$ & 0.003 & & -0.000 & 0.003 \\
\hline Observations & & 640 & & & 640 & \\
\hline
\end{tabular}

Table A.14 BMA estimation results for average growth rates of per capitaGDP: invest $\geq 3.10$ (renewable natural capital) $^{+}$

\begin{tabular}{lcccccc}
\hline \hline & \multicolumn{2}{c}{ Proximate and fundamental theories } & \multicolumn{3}{c}{ Fundamental theories } \\
\hline Explanatory variable & $\begin{array}{c}\text { Posterior } \\
\text { inclusion }\end{array}$ & Posterior & Posterior & Posterior & Posterior & Posterior \\
& probability & & standard & inclusion & mean & standard \\
& deviation & probability & & deviation
\end{tabular}

(\#)

(\#)

\begin{tabular}{|c|c|c|c|c|c|c|}
\hline \multicolumn{7}{|l|}{ Neoclassical } \\
\hline$\overline{\text { income_in }}$ & & $-0.071^{*}$ & 0.010 & & $-0.036^{*}$ & 0.011 \\
\hline рори. & & 0.041 & 0.063 & & & \\
\hline invest & & -0.058 & 0.032 & & & \\
\hline scho. & & -0.007 & 0.015 & & & \\
\hline Demography & 1.000 & & & & & \\
\hline life. & & 0.197 & 1.621 & & & \\
\hline fert. & & $-0.197 *$ & 0.031 & & & \\
\hline Macroeconomic policy & 0.924 & & & & & \\
\hline open & & -0.000 & 0.005 & & & \\
\hline gov. & & -0.005 & 0.049 & & & \\
\hline infl. & & $-0.275^{*}$ & 0.111 & & & \\
\hline Regional heterogeneity & 0.029 & & & & & \\
\hline lac & & 0.000 & 0.002 & & & \\
\hline ssa & & -0.000 & 0.003 & & & \\
\hline sea & & -0.000 & 0.006 & & & \\
\hline Religion & 0.971 & & & 1.000 & & \\
\hline eastern & & $0.290 *$ & 0.087 & & $0.423^{*}$ & 0.071 \\
\hline hindu & & 0.060 & 0.086 & & 0.186 & 0.104 \\
\hline muslim & & -0.001 & 0.008 & & -0.017 & 0.031 \\
\hline protestant & & 0.000 & 0.006 & & -0.001 & 0.008 \\
\hline other & & 0.008 & 0.037 & & 0.003 & 0.025 \\
\hline Natural capital & 0.165 & & & 0.378 & & \\
\hline natural_w_r & & -0.021 & 0.059 & & -0.073 & 0.113 \\
\hline natural_pc_r & & 0.000 & 0.000 & & 0.000 & 0.000 \\
\hline Geography & 0.094 & & & 0.039 & & \\
\hline coastline & & 0.001 & 0.014 & & 0.000 & 0.003 \\
\hline landlocked & & -0.003 & 0.012 & & 0.000 & 0.014 \\
\hline Fractionalization & 0.076 & & & 0.984 & & \\
\hline language & & -0.002 & 0.010 & & -0.001 & 0.012 \\
\hline ethnic & & -0.000 & 0.007 & & $-0.129 *$ & 0.039 \\
\hline
\end{tabular}




\begin{tabular}{|c|c|c|c|c|}
\hline Institutions & 1.000 & & 0.999 & \\
\hline$\overline{k k z 96}$ & -0.001 & 0.005 & 0.000 & 0.003 \\
\hline exe_constr & -0.008 & 0.004 & -0.001 & 0.005 \\
\hline Observations & 338 & & 338 & \\
\hline
\end{tabular}

Table A.15 BMA estimation results for average growth rates of per capita GDP: invest $<3.10$ (renewable natural capital) $^{+}$

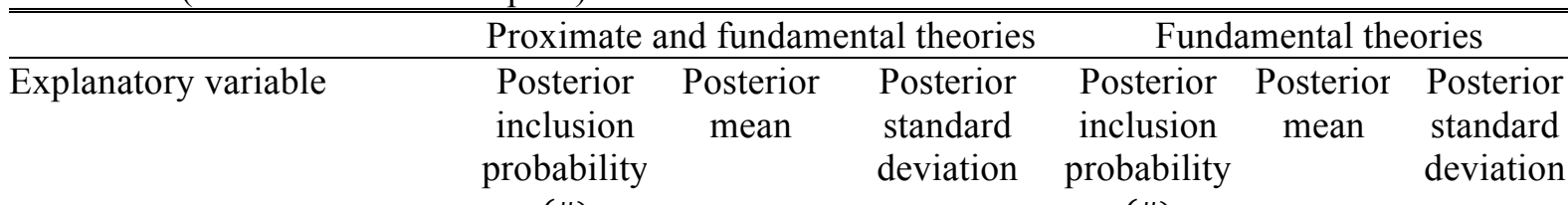

(\#)

(\#)

\begin{tabular}{|c|c|c|c|c|c|c|}
\hline \multirow{2}{*}{\multicolumn{7}{|c|}{ Neoclassical }} \\
\hline & & & & & & \\
\hline income_in & & -0.006 & 0.013 & & 0.003 & 0.009 \\
\hline рори. & & $-0.154 *$ & 0.086 & & & \\
\hline invest & & 0.035 & 0.022 & & & \\
\hline scho. & & -0.010 & 0.014 & & & \\
\hline Demography & 0.286 & & & & & \\
\hline life. & & -0.002 & 0.014 & & & \\
\hline fert. & & -0.027 & 0.051 & & & \\
\hline Macroeconomic policy & 0.042 & & & & & \\
\hline open & & -0.000 & 0.002 & & & \\
\hline gov. & & 0.001 & 0.027 & & & \\
\hline infl. & & -0.000 & 0.000 & & & \\
\hline Regional heterogeneity & 0.218 & & & & & \\
\hline lac & & 0.000 & 0.003 & & & \\
\hline ssa & & -0.011 & 0.027 & & & \\
\hline sea & & 0.000 & 0.007 & & & \\
\hline Religion & 0.167 & & & 0.004 & & \\
\hline$\overline{\text { eastern }}$ & & 0.065 & 0.050 & & 0.007 & 0.058 \\
\hline hindu & & 0.000 & 0.006 & & 0.000 & 0.008 \\
\hline muslim & & 0.024 & 0.011 & & 0.000 & 0.021 \\
\hline protestant & & -0.007 & 0.024 & & -0.001 & 0.012 \\
\hline other & & 0.012 & 0.050 & & 0.000 & 0.005 \\
\hline Natural capital & 0.220 & & & 0.524 & & \\
\hline$\overline{\text { natural_w_r }}$ & & -0.024 & 0.055 & & 0.076 & 0.058 \\
\hline natural_pc_r & & -0.000 & 0.000 & & -0.000 & 0.000 \\
\hline Geography & 0.050 & & & 0.057 & & \\
\hline coastline & & 0.000 & 0.006 & & -0.001 & 0.007 \\
\hline landlocked & & -0.000 & 0.006 & & 0.002 & 0.006 \\
\hline Fractionalization & 0.045 & & & 0.089 & & \\
\hline language & & 0.000 & 0.005 & & -0.000 & 0.007 \\
\hline ethnic & & 0.000 & 0.005 & & -0.002 & 0.012 \\
\hline Institutions & 0.999 & & & 1.000 & & \\
\hline$\overline{k k z 96}$ & & -0.005 & 0.013 & & 0.000 & 0.003 \\
\hline exe_constr & & -0.007 & 0.004 & & -0.002 & 0.004 \\
\hline Observations & & 308 & & & 308 & \\
\hline
\end{tabular}


Table A.16 BMA estimation results for average growth rates of per capita GDP: Full sample (nonrenewable natural capital) ${ }^{+}$

\begin{tabular}{|c|c|c|c|c|c|c|}
\hline \multirow[b]{2}{*}{ Explanatory variable } & \multicolumn{3}{|c|}{ Proximate and fundamental theories } & \multicolumn{3}{|c|}{ Fundamental theories } \\
\hline & $\begin{array}{l}\text { Posterior } \\
\text { inclusion } \\
\text { probability } \\
(\#)\end{array}$ & $\begin{array}{c}\text { Posterior } \\
\text { mean }\end{array}$ & $\begin{array}{l}\text { Posterior } \\
\text { standard } \\
\text { deviation }\end{array}$ & $\begin{array}{c}\text { Posterior } \\
\text { inclusion } \\
\text { probability } \\
(\#)\end{array}$ & $\begin{array}{c}\text { Posterior } \\
\text { mean }\end{array}$ & $\begin{array}{l}\text { Posterior } \\
\text { standard } \\
\text { deviation }\end{array}$ \\
\hline \multicolumn{7}{|l|}{ Neoclassical } \\
\hline income_in & & $-0.052 *$ & 0.008 & & $-0.012 *$ & 0.005 \\
\hline рори. & & -0.022 & 0.050 & & & \\
\hline invest & & 0.017 & 0.012 & & & \\
\hline scho. & & -0.003 & 0.010 & & & \\
\hline Demography & 1.000 & & & & & \\
\hline life. & & -0.007 & 0.025 & & & \\
\hline fert. & & $-0.164 *$ & 0.025 & & & \\
\hline Macroeconomic policy & 0.024 & & & & & \\
\hline open & & -0.000 & 0.001 & & & \\
\hline gov. & & -0.000 & 0.009 & & & \\
\hline infl. & & -0.000 & 0.000 & & & \\
\hline Regional heterogeneity & 0.049 & & & & & \\
\hline lac & & 0.000 & 0.001 & & & \\
\hline ssa & & -0.001 & 0.006 & & & \\
\hline sea & & 0.000 & 0.002 & & & \\
\hline Religion & 0.958 & & & 1.000 & & \\
\hline$\overline{\text { eastern }}$ & & $0.266^{*}$ & 0.084 & & $0.432 *$ & 0.062 \\
\hline hindu & & 0.001 & 0.012 & & 0.021 & 0.043 \\
\hline muslim & & 0.000 & 0.005 & & -0.001 & 0.006 \\
\hline protestant & & -0.003 & 0.011 & & -0.003 & 0.013 \\
\hline other & & 0.002 & 0.015 & & 0.001 & 0.013 \\
\hline Natural capital & 0.277 & & & 0.059 & & \\
\hline$\overline{\text { natural_w_nr }}$ & & -0.000 & 0.006 & & -0.001 & 0.009 \\
\hline natural_pc_nr & & 0.000 & 0.000 & & 0.000 & 0.000 \\
\hline Geography & 0.074 & & & 0.036 & & \\
\hline coastline & & -0.000 & 0.004 & & 0.000 & 0.005 \\
\hline landlocked & & -0.001 & 0.008 & & -0.000 & 0.003 \\
\hline Fractionalization & 0.044 & & & 0.993 & & \\
\hline$\overline{\text { language }}$ & & -0.000 & 0.004 & & -0.001 & 0.009 \\
\hline ethnic & & -0.000 & 0.004 & & $-0.093^{*}$ & 0.025 \\
\hline Institutions & 1.000 & & & 1.000 & & \\
\hline$k k z 96$ & & -0.000 & 0.003 & & 0.000 & 0.003 \\
\hline exe_constr & & $-0.007 *$ & 0.003 & & -0.000 & 0.003 \\
\hline Observations & & 640 & & & 640 & \\
\hline
\end{tabular}

${ }^{+}$A $" * "$ indicates significance of the coefficient associated with the corresponding proxy variable. The posterior inclusion probability of a theory is marked in bold when such a theory is relatively robust in explaining economic growth, i.e., when the variables used to proxy it are jointly significance, with robustness increasing as the probability gets close to one.

Table A.17 BMA estimation results for average growth rates of per capita GDP: invest $\geq 3.10$ (nonrenewable natural capital)

\begin{tabular}{|c|c|c|c|c|c|}
\hline & Proximate and fundam & ntal theories & Fun & lamental th & ories \\
\hline Explanatory variable & $\begin{array}{cc}\text { Posterior } & \text { Posterior } \\
\text { inclusion } & \text { mean } \\
\text { probability } & \end{array}$ & $\begin{array}{l}\text { Posterior } \\
\text { standard } \\
\text { deviation }\end{array}$ & $\begin{array}{l}\text { Posterior } \\
\text { inclusion } \\
\text { probability }\end{array}$ & $\begin{array}{c}\text { Posterior } \\
\text { mean }\end{array}$ & $\begin{array}{l}\text { Posterior } \\
\text { standard } \\
\text { deviation }\end{array}$ \\
\hline
\end{tabular}

Neoclassical

(\#) 


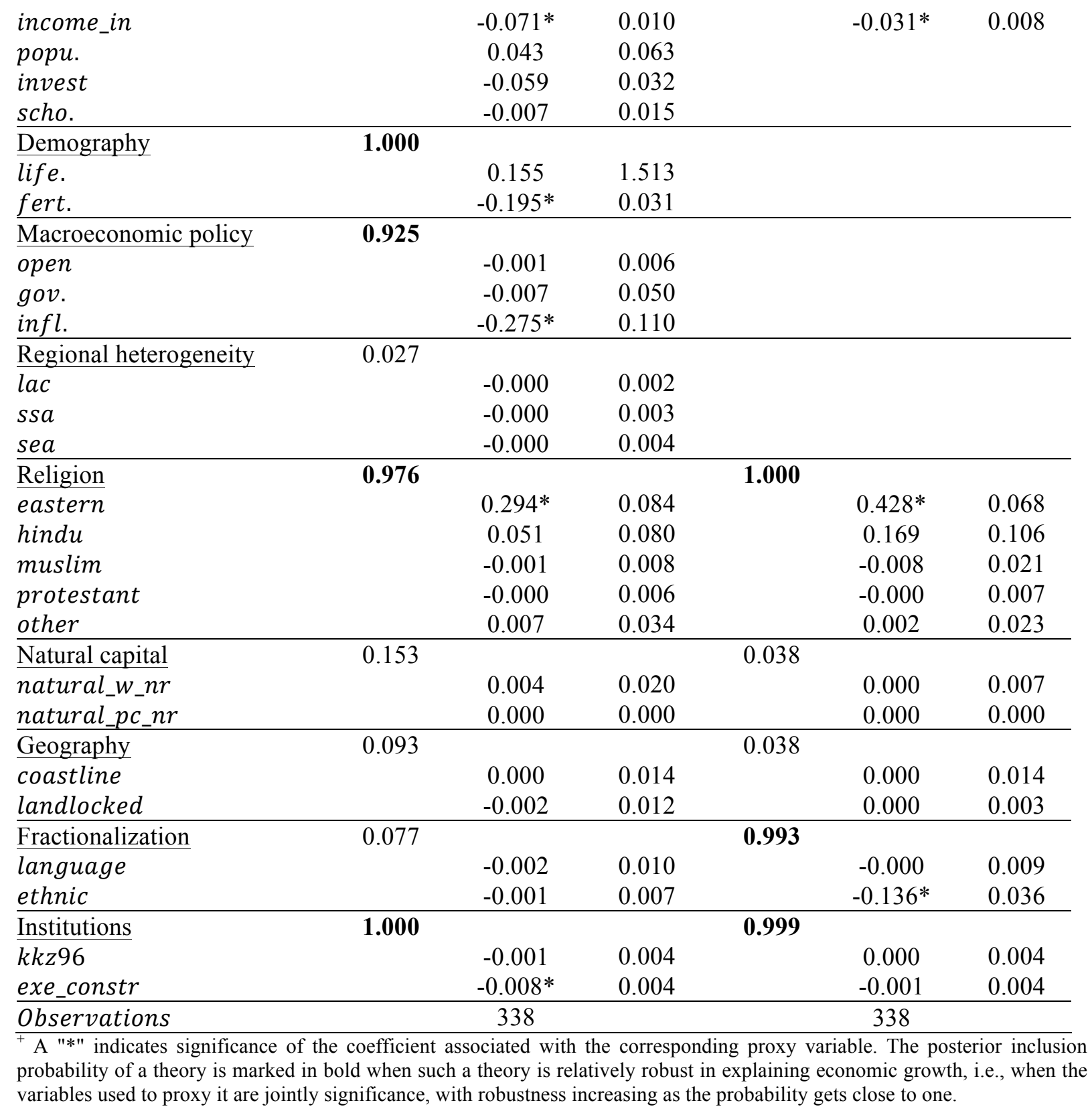

Table A.18 BMA estimation results for average growth rates of per capita GDP: invest $<3.10$ (nonrenewable natural capital $)^{+}$

\begin{tabular}{|c|c|c|c|c|c|c|}
\hline \multirow[b]{2}{*}{ Explanatory variable } & \multicolumn{3}{|c|}{ Proximate and fundamental theories } & \multicolumn{3}{|c|}{ Fundamental theories } \\
\hline & $\begin{array}{c}\text { Posterior } \\
\text { inclusion } \\
\text { probability } \\
\text { (\#) }\end{array}$ & $\begin{array}{l}\text { Posterior } \\
\text { mean }\end{array}$ & $\begin{array}{l}\text { Posterior } \\
\text { standard } \\
\text { deviation }\end{array}$ & $\begin{array}{c}\text { Posterior } \\
\text { inclusion } \\
\text { probability } \\
(\#)\end{array}$ & $\begin{array}{c}\text { Posterio } \\
\text { mean }\end{array}$ & $\begin{array}{l}\text { Posterior } \\
\text { standard } \\
\text { deviation }\end{array}$ \\
\hline \multicolumn{7}{|l|}{ Neoclassical } \\
\hline income_in & & -0.005 & 0.013 & & 0.010 & 0.007 \\
\hline рори. & & $-0.154^{*}$ & 0.090 & & & \\
\hline invest & & 0.037 & 0.022 & & & \\
\hline scho. & & -0.010 & 0.014 & & & \\
\hline Demography & 0.317 & & & & & \\
\hline life. & & -0.002 & 0.015 & & & \\
\hline fert. & & -0.031 & 0.053 & & & \\
\hline
\end{tabular}

Macroeconomic policy

0.039 


\begin{tabular}{|c|c|c|c|c|c|c|}
\hline $\begin{array}{l}\text { open } \\
\text { gov. } \\
\text { infl. }\end{array}$ & & $\begin{array}{c}-0.000 \\
0.000 \\
-0.000\end{array}$ & $\begin{array}{l}0.002 \\
0.017 \\
0.001\end{array}$ & & & \\
\hline Regional heterogeneity & 0.190 & & & & & \\
\hline lac & & 0.000 & 0.003 & & & \\
\hline ssa & & -0.009 & 0.025 & & & \\
\hline sea & & 0.000 & 0.007 & & & \\
\hline Religion & 0.181 & & & 0.007 & & \\
\hline$\overline{\text { eastern }}$ & & 0.007 & 0.053 & & 0.012 & 0.974 \\
\hline hindu & & 0.000 & 0.006 & & 0.001 & 0.009 \\
\hline muslim & & 0.002 & 0.012 & & 0.000 & 0.003 \\
\hline protestant & & -0.008 & 0.026 & & -0.003 & 0.016 \\
\hline other & & 0.012 & 0.050 & & 0.000 & 0.006 \\
\hline Natural capital & 0.079 & & & 0.124 & & \\
\hline natural_w_nr & & -0.001 & 0.010 & & -0.006 & 0.022 \\
\hline natural_pc_nr & & 0.000 & 0.000 & & 0.000 & 0.000 \\
\hline Geography & 0.051 & & & 0.068 & & \\
\hline coastline & & 0.000 & 0.006 & & 0.000 & 0.006 \\
\hline landlocked & & -0.000 & 0.006 & & -0.002 & 0.009 \\
\hline Fractionalization & 0.044 & & & 0.095 & & \\
\hline language & & 0.000 & 0.005 & & -0.000 & 0.006 \\
\hline ethnic & & -0.000 & 0.006 & & 0.003 & 0.014 \\
\hline Institutions & 0.999 & & & 0.999 & & \\
\hline$k k z 96$ & & -0.005 & 0.014 & & 0.000 & 0.003 \\
\hline exe_constr & & -0.007 & 0.004 & & -0.003 & 0.004 \\
\hline Observations & & 308 & & & 308 & \\
\hline
\end{tabular}

\section{References}

Acemoglu D, Johnson S, Robinson J (2002) The colonial origins of comparative development: an empirical investigation. American Economic Review 91(5): 1369-1401.

Acemoglu D, Johnson S, Robinson, J (2005) Institutions as a fundamental cause of long-run growth. In: Aghion P, Durlauf S (eds.), Handbook of Economic Growth, Elsevier, Amsterdam, The Netherlands.

Acemoglu D, Robinson J (2012) Why nations fail: The origins of power, prosperity and poverty. Crown publishers, New York.

Ades A, Di Tella R (1999) Rents, competition and corruption. American Economic Review 89(4): 982-993.

Alesina A, Ozler S, Roubini N, Swagel P (1996) Political instability and economic growth. Journal of Economic Growth 1(2): 189-211.

Alesina A, Devleeschauwer A, Easterly W, Kurlat S, Wacziarg R (2003) Fractionalization. Journal of Economic Growth 8(2): 155-194.

Aliyev I (2011) Understanding the resource impact using matching. CERGE-EI Working Papers Series No. 451.

Andersson BA, Råde I (2002) Material constraints on technology evolution: The case of scarce metals and emerging energy technologies. In: Ayres RU, Ayres LW (eds.), Handbook of Industrial Ecology, Edward Elgar, Cheltenham, UK.

Arellano M, Bond S (1991) Some tests of specification for panel data: Monte Carlo evidence and an application to employment equations. Review of Economic Studies 58(2): 277-97. 
Arellano M, Bover O (1995) Another look at the instrumental variable estimation of errorcomponents models. Journal of Econometrics 68: 29-51.

Ashraf QH, Weil DN, Wilde J (2013) The effects of fertility reduction of economic growth. Population and Development Review 39(1): 97-130.

Barbier EB (2014) Accounting for depreciation of natural capital. Nature 515: 32-33.

Barbier EB (2017) Natural capital and wealth in the 21st century. Eastern Economic Journal 43(3): 391-405.

Bardini C (1997) Without coal in the age of steam: A factor-endowment explanation of the Italian industrial lag before World War I. Journal of Economic History 57: 633-653.

Barro R (1991) Economic growth in a cross section of countries. Quaterly Journal of Economics 106(2): 407-43.

Barro R (1996) Democracy and growth. Journal of Economic Growth 1(1): 1-27.

Barro R (1997) Determinants of economic growth. MIT Press, Cambridge, USA.

Barro R, Lee JW (1994) Sources of economic growth. Carnegie-Rochester Conference Series on Public Policy, Elsevier, 40(1): 1-46.

Barro R, Lee JW (2014) A new data set of educational attainment in the world, 1950-2010. Journal of Development Economics 104: 184-198.

Barro R, McCleary R (2003) Religion and economic growth across countries. American Sociological Review 68(5): 760-781.

Barro RJ, Sala-i-Martin X (1992) Convergence. Journal of Political Economy 100(2): 223-251.

Bartlett JE, Kotrlik JW, Higgins CC (2001) Organizational research: Determining appropriate sample size in survey research. Information Technology, Learning, and Performance Journal 19(1): 43-50.

Beck T, Clarke G, Groff A, Keefer P, Walsh P (2001) New tools in comparative political economy: The database of political institutions. World Bank Economic Review 15(1): 165176.

Bloom DE, Sachs JD, Collier P., Udry C (1998) Geography, demography, and economic growth in Africa. Brookings Papers Economic Activity 2: 207-73.

Boschini A, Pettersson J, Roine J (2013) The resource curse and its potential reversal. World Development 43: 19-41.

Brock W, Durlauf SN (2001) Growth empirics and reality. World Bank Economic Review 15(2): 229-272.

Brock W, Durlauf SN, West K (2003) Policy analysis in uncertain economic environments (with discussion). Brookings Papers on Economic Activity 1: 235-322.

Brunnschweiler CN, Bulte EH (2008) Linking natural resources to slow growth and more conflict. Science 320(5876): 616-617.

Bruno M, Sachs J (1982) Energy and resource allocation: A dynamic model of the "Dutch Disease." The Review of Economic Studies 49(5): 845-859.

Bruno M, Easterly W (1998) Inflation crises and long-run growth. Journal of Monetary Economics 41(1): 3-26.

Capolupo R (2009) The new growth theories and their empirics after twenty years. OpenAssessment E-Journal, Kiel Institute for the World Economy 3: 1-72.

Caselli F, Esquivel G, Lefort F (1996) Reopening the convergence debate: A new look at crosscountry growth empirics. Journal of Economic Growth 1(3): 363-389.

Caselli F (2005) Accounting for cross-country income differences. In: Handbook of Economic Growth, Aghion P, Durlauf S (eds.), Elsevier, Amsterdam, The Netherlands.

Central Intelligence Agency (2009) The World Factbook 2009, ISSN 1553-8133, Washington DC, USA.

Cerny A, Filer RK (2007) Natural resources: Are they really a curse?. CERGE-EI Working Paper Series No. 321. 
Chan KMA, Satterfield T, Goldstein J (2011) Rethinking ecosystem services to better address and navigate cultural values. Ecological Economics 74: 8-18.

Chen $\mathrm{D}, \mathrm{Ma} \mathrm{X}, \mathrm{Mu}, \mathrm{H}, \mathrm{Li} \mathrm{P}$ (2010) The inequality of natural resources consumption and its relationship with the social development level based on the ecological footprint and the HDI. Journal of Environmental Assessment Policy and Management 12(1): 69-86.

Conservation international (2019) Valuing natural capital: Accounting for the benefits that nature provides: https://www.conservation.org/projects/valuing-and-accounting-for-naturalcapital

Costanza R, d'Arge R, de Groot R et al. (1997) The value of the world's ecosystem services and natural capital. Nature 387: 253-260.

Costanza R, de Groot R, Sutton P, van der Ploeg S, Anderson SJ, Kubiszewski I, Farber S, Turner RK (2014) Changes in the global value of ecosystem services. Global Environmental Change 26: 152-158.

Cox GW, Weingast BR (2018) Executive constraint, political stability and economic growth. Comparative Political Studies, 51(3): 279-303.

Daily G (1997) Introduction: What are ecosystem services?. In: Daily G (ed.), Nature's Services. Societal Dependence on Natural Ecosystems. Island Press, Washington DC, USA.

Daly HE, Farley J (2004) Ecological economics: Principles and applications. Island Press, Washington DC, USA.

De Long JB, Williamson JB (1994) Natural resources and convergence in the nineteenth and twentieth centuries. Harvard University, USA.

Diaz S, Unai P, Stenseke M et al. (2018) Assessing nature's contributions to people. Science, 359(6373): 270-272.

Ding N, Field BC (2005) Natural resource abundance and economic growth. Land Economics 81(4): 496-502.

Dinh HT, Dinh R (2016) Managing natural resources for growth and prosperity in low income countries. OCP Policy Center Policy Paper 16/01.

Djankov S, La Porta R, Lopez-de-Silanes F, Shleifer A (2002) The regulation of entry. Quarterly Journal of Economics 117(1): 1-37.

Djankov S, La Porta R, Lopez-de-Silanes F, Shleifer A (2003) Courts. Quarterly Journal of Economics 118, 453-518.

Driscoll J, Kraay AC (1998) Consistent covariance matrix estimation with spatially dependent data. Review of Economics and Statistics 80: 549-560.

Durlauf SN, Johnson PA (1995) Multiple regimes and cross-country growth behaviour. Journal of Applied Econometrics 10(4): 365-384.

Durlauf SN, Johnson PA, Temple JRW (2005) Growth econometrics. In: Durlauf SN, Aghion P (eds.), Handbook of Economic Growth, Elsevier, Amsterdam, The Netherlands.

Durlauf SN, Kourtellos A, Tan, CM (2008a) Are any growth theories robust?. The Economic Journal 118(527): 329-346.

Durlauf SN, Kourtellos A, Tan CM (2008b) Empirics of growth and development. In: Dutt AK, Ros J (eds.), International Handbook of Development Economics 1, Edward Elgar, Cheltenham, UK.

Durlauf SN, Kourtellos A, Tan CM (2012) Is God in the details? A re-examination of the role of religion in economic growth. Journal of Applied Econometrics 27(7):1059-1075.

Durlauf SN, Quah DT (1999) The new empirics of economic growth. In: Taylor JB, Woodford M. (eds.), Handbook of Macroeconomics, vol. 1, Elsevier, Amsterdam, The Netherlands.

Easterly W (2001) The lost decades: Explaining developing countries' stagnation in spite of policy reform 1980-1998. Journal of Economic Growth 6(2): 135-157.

Easterly W, Levine R (1997) Africa's growth tragedy: Policies and ethnic divisions. Quarterly Journal of Economics 112(4): 1203-50. 
Edenhofer O (2015) King coal and the queen of subsidies. Science 349(6254): 1286-1287.

Fernandez C, Ley E, Steel MFJ (2001) Model uncertainty in cross-country growth regressions. Journal of Applied Econometrics 16(5): 563-576.

Frankel, 2010. The natural resource curse: A survey. National Bureau of Economic Research Working Paper No. 15836.

Glaeser EL, La Porta R, Lopez-de-Silanes F, Shleifer A (2004) Do institutions cause growth?. Journal Economic Growth 9(3): 271-303.

Goedkoop M, Heijungs R, Huijbregts M, De Schryver A, Struijs J, Van Zelm R (2008) ReCiPe 2008: A life cycle impact assessment method which comprises harmonised category indicators at the midpoint and the endpoint level. First edition. Report I: Characterisation. Dutch Ministry of the Environment, The Hague, The Netherlands.

Gowdy JM, Howarth RB, Tisdell C (2009) Discounting, ethics and options for maintaining biodiversity and ecosystem integrity. In: The Economics of Ecosystems and Biodiversity (TEEB): Ecological and Economic Foundations, Kumar, P. (ed.), Abingdon: Routledge.

Gylfason T (2001) Natural resources, education, and economic development. European Economic Review 45(4): 847-859.

Gylfason T (2011) Natural resource endowment: A mixed blessing? In: Sy A, Arezki R, Gylfason T (eds.), Beyond The Curse: Policies to Harness The Power of Natural Resources, IMF e-Library.

Hall RE, Jones CI (1999) Why do some countries produce so much more output per worker than others? The Quarterly Journal of Economics 114(1): 83-116.

Hox J (2002) Multilevel analysis. Techniques and applications. Lawrence Erlbaum, Mahwah, NJ, USA.

Hox J (2010) Multilevel analysis: Techniques and applications. Second edition. Routledge, New York, USA.

IPBES (2019) Summary for policymakers of the global assessment report on biodiversity and ecosystem services of the Intergovernmental Science-Policy Platform on Biodiversity and Ecosystem Services. https://www.ipbes.net/news/ipbes-global-assessment-summarypolicymakers-pdf.

Kaufmann D, Kraay A, Mastruzzi M (2005) Governance matters IV: Governance indicators for 1996-2004. World Bank Policy Research Working Paper 3630.

Kelley AC, Schmidt RM (1995) Aggregate population and economic growth correlations: The role of the components of demographic change. Economic Demography 32(4): 543-555.

Konte M (2013) A curse or a blessing? Natural resources in a multiple growth regimes analysis. Applied Economics 45(26): 3760-3769.

La Porta R, Lopez-de-Silanes F, Shleifer A, Vishny R (1999) The quality of government. Journal of Law, Economics, and Organization 15(1): 222-279.

Laurans Y, Rankovic A, Billé R, Pirard R, Mermet, L (2013) Use of ecosystem services economic valuation for decision making: Questioning a literature blindspot. Journal of Environmental Management 15(119): 208-19.

Lederman D, Maloney W (2002) Open questions about the link between natural resources and economic growth: Sachs and Warner revisited. Central Bank of Chile Working Paper 141.

Lederman D, Maloney W (2008) In search of the missing resource curse. Policy Research Working Paper No. 4766. World Bank.

Lenzen M, Moran D, Kanemoto K et al. (2012) International trade drives biodiversity threats in developing nations. Nature 486: 109-112.

MAEDI (2014) Innovative financing mechanism for biodiversity and the identification of mechanisms with strong potential. French Ministry of Foreign Affairs and International Development, Paris, France. 
Malthus TR (1798) An essay on the principle of population. Oxford University Press, Oxford, UK.

Mankiw NG, Romer D, Weil DN (1992) A contribution to the empirics of economic growth. The Quarterly Journal of Economics 107(2): 407-437.

Mansano O, Ribogon R (2001) Resource curse or debt overhang?. National Bureau of Economic Research Working Paper No. 8390.

McGlade C, Ekins P (2015) The geographical distribution of fossil fuels unused when limiting global warming to 2 [deg] C. Nature 517: 187-190.

Mehlum H, Moene K, Torvik R (2006) Institutions and the resource curse. The Economic Journal 116(508): 1-20.

Millennium Ecosystem Assessment (MEA) (2005) Four Volumes: Current State and Trends; Scenarios; Policy Responses; Sub-Global Assessments. Island Press, Washington D.C., USA.

Moral-Benito E (2012) Determinants of economic growth: A Bayesian panel data approach. The Review of Economics and Statistics 94(2): 566-579.

Newbold T, Hudson, NL, Arnell AP et al. (2016) Has land use pushed terrestrial biodiversity beyond the planetary boundary? A global assessment. Science 353(6296): 288-291.

Norman C (2009) Rule of law and the resource curse: Abundance versus intensity. Environmental and Resource Economics 43, 2, 183-207.

Omgba LD (2015) Why do some oil-producing countries succeed in democracy while other fail?. World Development 76: 180-189.

Owen A, Videras J, Davis L (2007) Do all countries follow the same growth process?. Journal of Economic Growth 14(4): 265-286.

Pearce DW, Markandya A, Barbier E (1989) Blueprint for a green economy. Earthscan, London, United Kingdom.

Petersen JE, Gocheva K (2015) EU reference document on Natural Capital Accounting. Prepared as part of the EU MAES process (Mapping and Assessment of Ecosystems and their Services), revised draft for consultation, January, 6, 2015.

Pomeranz K (2000) The great divergence: China, Europe, and the making of the modern world economy. Princeton University Press, Princeton, USA.

Recuero Virto L, Weber JL, Jeantil M (2018) Natural capital accounts and public policy decisions: Findings from a survey. Ecological Economics 144: 244-259.

Repetto R, Magrath W, Wells M, Beer C, Rossini F (1989) Wasting Assets: Natural Resources in the National Income Accounts. NewYork: World Resource Institute.

Reynolds DB (1999) The mineral economy: How prices and costs can falsely signal decreasing scarcity. Ecological Economics 31(1): 155-166.

Rockström J, Steffen W, Noone K et al. (2009) A safe operating space for humanity. Nature 461: 472-475.

Rodrik D (2003) Search of prosperity: Analytic narratives on economic growth. Princeton University Press, Princeton, USA.

Roodman D (2009) A note on the theme of too many instruments. Oxford Bulletin of Economics and Statistics 71(1): 135-158.

Ross M (2015) What have we learned from the resource curse?. Annual Review of Political Science 18: 1-499.

Sachs J (2003) Institutions don't rule: Direct effects of geography on per capita income. National Bureau of Economic Research Working Paper No. 9490.

Sachs J, Warner A (1995) Economic reform and the process of global integration. Brooking Papers on Economic Activity 26(1): 1-118.

Sachs J, Warner A (2001) The curse of natural resources. European Economic Review 45(4-6): 827-838. 
Sala-i-Martin X, Doppelhofer G, Miller R (2004) Determinants of long-term growth: A Bayesian averaging of classical estimates (BACE) approach. American Economic Review 94(4): 813-35.

Shahbaz M, Destek MA, Okumus I, Sinha A (2019) An empirical note on comparison between resource abundance and resource dependence in resource abundant countries. Resources Policy $60:$ 47-55.

Shastry GK, Weil DN (2003) How much of cross-country income variation is explained by health. Journal of the European Economic Association 1:387-396.

Sleeswijk A, van Oers L, Guinee JB, Struijs J, Huijbregts MAJ (2008) Normalisation in product life cycle assessment: An LCA of the global and European economic systems in the year 2000. Science of the Total Environment 390(1): 227-240.

Stanford Advisory Council (2006) The natural capital project. Stanford University. https://naturalcapitalproject.stanford.edu.

Steel MFJ (2019) Model averaging and its use in economics. Journal of Economic Literature. .doi:10.1257/jel.20191385 (In Press).

Solow RM (1956) A contribution to the theory of economic growth. The Quarterly Journal of Economics 70(1): 65-94.

Stiglitz JE, Sen A, Fitoussi JP (2009) The measurement of economic performance and social progress revisited. Document de Travail de l'OFCE N 2009-33.

Stijns JP (2005) Natural resource abundance and economic growth revisited. Resources Policy $30,2,107-130$.

Sutton P, Anderson SJ, Costanza R, Kubiszewski I (2016) The ecological economics of land degradation: Impacts on ecosystem service values. Ecological Economics 129: 182-192.

ten Brink P, Russi D, Tinch R, Schoumacher C, Agarwala M, Bateman I (2015) The use of (economic \& social) values of NC/ES in national accounting. D3.4 Discussion Paper, European Commission (OPERA project).

The Economics of Ecosystems and Biodiversity-TEEB (2008) An interim report, European Communities, Brussels, Belgium.

Torres N, Afonso O, Soares I (2013) A survey of literature on the resource curse: Critical analysis of the main explanations, empirical tests and resource proxies. CEF.UP Working Papers 1302, Faculdade de Economia do Port, Universidade do Porto.

Torvik R (2009) Why do some resource-abundant countries succeed while others do not? Oxford Review of Economic Policy 25(2): 241-256.

UNEP (2015) The UNEP Environmental Data Explorer, as compiled from World Resources Institute. United Nations Environment Programme, Nairobi, Kenya.

van der Ploeg F (2010) Natural resources: Curse or blessing?. Journal of Economic Literature 49(2): 366-420.

van der Ploeg F, Poelhekke S (2010) The pungent smell of 'red herrings': Subsoil assets, rents, volatility and the resource curse. Journal of Environmental Economics and Management 60(1): 44-55.

van der Ploeg F, Venables AJ (2013) Absorbing a windfall of foreign exchange: Dutch disease dynamics. Journal of Development Economics 103:229-243.

Weber JL (2014) Ecosystem natural capital accounts: a quick start package. CBD Technical Series No. 77.

Weil DN (2005) Accounting for the effect of health on economic growth. National Bureau of Economic Research Working Paper 11455.

World Bank (2006) A guide to valuing natural resources wealth. Environment Department, World Bank, USA.

World Bank (2011) The changing wealth of nations : Measuring sustainable development in the new millennium. Environment and development. World Bank Group. 
World Bank (2018) The changing wealth of nations : Building a sustainable future. Lange GM, Wodon Q, Carey K (eds). World Bank Group.

World Christian Encyclopedia (2001) Oxford University Press.

Worldwide Fund for Nature (WWF) (2015) From obstacles to opportunities - Towards an action plan for improved natural capital and ecosystem accounting implementation. WWF, Brussels, Belgium. 